\title{
Review and Assessment of the Georges Bank and Gulf of Maine Haddock Fishery
}

\author{
Stephen H. Clark, William J. Overholtz and Richard C. Hennemuth \\ National Marine Fisheries Service, Northeast Fisheries Center \\ Woods Hole, Massachusetts 02543, USA
}

\begin{abstract}
The Georges Bank and Gulf of Maine haddock resource and fishery is reviewed. Nominal catches for Georges Bank averaged 46,000 metric tons annually during $1935-60$ and then increased to a peak of 150,000 tons in 1965 as Canadian and distant water (European) fleets entered the fishery. Catches subsequently declined to an average of 5,000 tons during 1974-76 under quota and incidental catch limitations and then increased rapidly to an average of 21,000 tons in 1978-79. Nominal catches for the Gulf of Maine averaged 5,000 tons during 1935-66, declined to less than 1,000 tons during 1972-74 and increased to an average of 5,000 tons in 1978-79. Minor recreational catches have also been reported from the western Gulf of Maine in recent years.
\end{abstract}

Total stock size (age 2 and older haddock) for Georges Bank, determined from virtual population analysis, averaged 140 million fish (153,000 tons) during 1935-60, increased to 530 million fish (427,000 tons) in 1965 and declined precipitously to 8 million fish $(22,000$ tons) in 1972. Subsequently, there was a substantial increase in stock size due to recruitment of the 1975 year-class. The 1978 year-class appears to be comparable in size to that of 1975. Instantaneous fishing mortality (F) for age 3 and older fish averaged 0.44 during 1935-60, increased to a peak of 0.79 in 1966 and subsequently declined as abundance decreased and fishing effort was diverted to other species. Trends in abundance and mortality evidenced by data from research vessel surveys since 1963 have been generally consistent with those indicated by virtual population analysis. Variability in growth of Georges Bank haddock during 1931-65 and pronounced eitanges in the late 1960's and early 1970's appear primarily attributable to changes in abundance. Reduction in spawning stock biomass during the late 1960's and early 1970's was associated with low recruitment and increased variability in year-class size. Trends in abundance for the Gulf of Maine were similar to those observed for Georges Bank, although discrepancies were evident in relative strengths of recent year-classes.

\section{Introduction}

The haddock, Melanogrammus aeglefinus (L.), has supported the groundfish fishery of the New England area of the United States of America (USA) for many decades. Prior to 1900 , this species was of minor importance commercially, being inferior to Atlantic cod, Gadus morhua, for salting purposes. Nominal catches (live weight equivalent of landings) were relatively constant during the $1880-1903$ period, averaging about 24,500 (metric) tons annually (Power, 1958). In the early days of the fishery, the catch was taken primarily by hand-lines and line-trawls, but the VigneronDahl trawl was introduced in 1905 and became the more prominant gear by 1920 . Initially, haddock were usually marketed fresh, and until the 1920's catch trends were determined primarily by market demand for fresh fish. During that decade, however, increased demand for haddock, associated with introduction of filleting and quick-freezing techniques at dockside (Schuck, 1951; Power 1958), expansion of ice-making facilities, use of trawls, and introduction of diesel engines (Smith and Olsen, MS 1976), resulted in rapid expansion of the fishery, and the total USA catch of haddock in the Northwest Atlantic increased rapidly from 41,200 tons in 1921 to a peak of 132,200 tons in 1929. During this period, the bulk of the catch was taken on Georges Bank and in the Gulf of Maine
(NAFO Subarea 5), although substantial quantities were also taken on Browns Bank (NAFO Division 4X) and areas farther eastward (Fig. 1). Subsequently, the

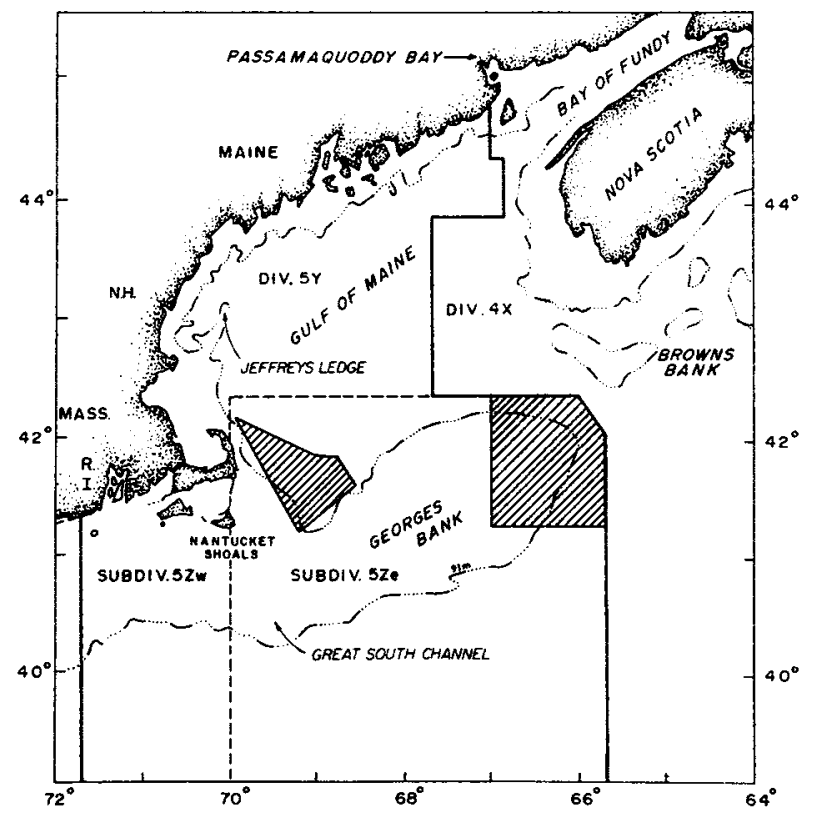

Fig. 1. Georges Bank and Gulf of Maine areas with place names and boundaries of divisions mentioned in the text. (Crosshatched areas are subject to seasonal closure.) 
USA catch declined sharply to an average of 75,400 tons annually during 1932-34 and stabilized at an average level of 70,300 tons during 1935-60. Over this period, USA catches from the Georges Bank-Gulf of Maine area averaged about 52,000 tons.

The entrance of distant-water fleets to the Georges Bank (Div. 5Z) fishery in the 1960's resulted in pronounced changes in haddock abundance and productivity. Catches on Georges Bank peaked at 150,400 tons in 1965 and subsequently declined to only 4,300 tons in 1974 due to poor recruitment and redirection of fishing effort to other species. In recent years, recruitment has improved and catches have increased, but abundance, age structure and other biological features have remained very different from the situation in 1935-60. Similar changes occurred in the Gulf of Maine (Div. 5Y), although catches by distant-water fleets appear to have been minimal.

The objectives of this paper are to review available biological and fishery-related data for Georges Bank and Gulf of Maine haddock, to provide an analytical assessment of the Georges Bank stock together with available assessment information for the Gulf of Maine, and to evaluate the implications of recent changes in abundance with respect to recruitment and growth.

\section{History of Research}

Georges Bank haddock have received intensive study, and a large volume of biological and statistical data has been assembled and published for this fishery. Organized research began in 1930, when funding was made available to the U.S. Bureau of Fisheries for haddock research in response to industry concern over rapidly declining landings and abundance (Schuck, 1951). Beginning in 1931, haddock landings were intensively sampled at major ports (Boston and Gloucester, Massachusetts, and Portland, Maine); data were collected on quantities landed by area (Rounsefell, 1948), size and age compositions, and other biological features, e.g. length-weight relationships. Much of the information for 1931-56 has been summarized by Schuck (1951), Clark and Dreyer (1961), and McCann and Dreyer (1963). Later material was published in the Sampling Yearbook series of the International Commission for the Northwest Atlantic Fisheries (ICNAF) and was also incorporated into assessment papers and other documents. Catch and effort data were collected and used for evaluation of trends in abundance (Schuck, 1949; Rounsefell, 1957) and for predictive purposes (Royce and Schuck, 1954). Considerable attention was also focused on discarding of small haddock (Herrington, 1935, 1936; Premetz, 1953). Other earlier contributions include studies on migration and stock identification (Needler, 1930;
Schroeder, 1942; Schuck and Arnold, 1951), stockrecruitment (Herrington, 1948), and the influence of currents on larval distribution and survival (Walford, 1938).

During the 1950's, interest focused on gear selectivity (Graham, 1952; Clark, 1952) and evaluation of mesh regulations (Graham and Premetz, 1955; Clark, 1963). Colton (1955) studied seasonal distribution of haddock, Chase (1955) and Colton and Temple (1961) examined environmental influences on year-class size, and Clark and Vladykov (1960) and Grosslein (1962) provided further information on stock boundaries.

More recent work has been oriented largely toward stock assessment. Hennemuth (MS 1968, MS 1969) assessed the status of the Georges Bank stock and examined trends in abundance, mortality and recruitment; this work was subsequently updated by Clark and Overholtz (MS 1979) and Clark and Essig (MS 1980). Grosslein and Hennemuth (1973) reviewed factors affecting recruitment, and Grosslein (MS 1969) devised young-of-year indices based on bottom-trawl survey data. Hennemuth (1965) analyzed commercial age-length data to evaluate sampling and reporting requirements, Brown and Hennemuih (1971) provided length-weight equations and conversion factors for commercial landings, and Stern and Hennemuth (1975) applied Robson's two-factor analysis-ofvariance approach to catch-effort data. Papers by Colton (1965) on distribution of eggs, larvae and juveniles and by Marak and Livingstone (1970) on spawning should also be noted.

\section{Management}

Prior to 1951, there was no legal basis for fishery management in international waters of the Northwest Atlantic. However, the need for management of the Georges Bank haddock fishery, to increase yield for a given level of fishing effort, was clearly demonstrated by extensive discarding of small haddock in the 1930's and 1940's (Herrington, 1936; Premetz, 1953; Graham and Premetz, 1955) which resulted from the use of trawl codends with stretched mesh sizes averaging 2.9 inches $(73 \mathrm{~mm})$. Establishment of ICNAF in 1951 provided an authority for management, and in June 1953 a regulation specifying a minimum mesh size of 4.5 inches $(114 \mathrm{~mm})$ in the trawl body and codend became effective for Subarea 5 (ICNAF, 1952). This regulation persisted with minor modifications until 1974, when the minimum codend mesh size was increased to 130 $\mathrm{mm}$ (5.1 inches). The regulation substantially increased harvesting efficiency (Graham and Premetz, 1955) and also appears to have reduced the quantities of haddock discarded from an average of $10-15 \%$ to 
about $1-5 \%$ of the nominal catch (Grosslein and Hennemuth, 1973). Attempts have been made to evaluate the actual effect of this regulation on yield per recruit and total yield, but this has been difficult to quantify due to improved recruitment following its implementation.

Events during the 1960's substantially changed the status of the haddock resource in Subarea 5 and resulted in more intensive conservation measures. The documented severe reduction in abundance of Georges Bank haddock by 1969 led to the establishment under ICNAF of a total allowable catch (TAC) of 12,000 tons for 1970 and 1971 (ICNAF, 1969). The TAC was reduced to 6,000 tons for 1972 and 1973 and to zero (except for incidental by-catch) for 1974. The TAC was set at 6,000 tons for 1975 and 1976, as it was considered that a TAC would be more effective in controlling fishing mortality. These conservation measures were supplemented by closure of major haddock spawning areas to demersal trawling during MarchApril since 1970 (ICNAF, 1969), with subsequent minor modifications in boundary lines, duration of closure and gear restrictions (Fig. 1).

In 1977, the New England Regional Fishery Management Council assumed exclusive responsibility for management of the Georges Bank and Gulf of Maine haddock stock under the USA Fishery Conservation and Management Act of 1976. The Council adopted a fishery management plan which in effect continued previous management measures for haddock implemented under ICNAF. The objective of the resulting management system was to set an optimum yield (OY)' so as to achieve the greatest possible economic and social net benefits from the groundfish resource while ensuring that, by the end of the period covered by the plan, relevant stocks would be at levels which would produce enhanced and relatively stable yields. An or of 6,200 tons $(6,000$ tons commercial, 200 tons recreational) was established for 1977 to be taken as incidental by-catch. Recruitment of the large 1975 year-class in 1977, together with a rapid increase in USA harvesting capacity and fishing effort, led to a series of increases in the $O Y$ and modifications in allocation schemes during 1977-78, culminating in removal of incidental catch limitations and an increase in the or to 20,000 tons in July 1978 , of which 16,900 tons were allocated for USA interests and 3,100 tons for Canada.

Management on a "fishing year" (October-September) rather than on a calendar year basis was implemented in October 1978. This permitted more timely use of autumn bottom-trawl survey data in determining the annual $O Y$, i.e. autumn survey data could be used in winter or spring assessments and also as the basis for establishing the OY for the succeeding fishing year. Consequently, an assessment in January 1979, which indicated a substantial increase in spawning stock size and improved recruitment prospects (Clark and Overholtz, MS 1979), led to an OY for Subarea 5 of 28,254 tons for the $1978 / 79$ fishing year and 32,500 tons for the $1979 / 80$ fishing year, corresponding to an instantaneous fishing mortality $(F)$ equal to the Fo.1 level (Gulland and Boerema, 1973). USA and Canadian allocations were 25,154 and 3,100 tons respectively for $1978 / 79$ and 27,250 and 5,250 tons for $1979 / 80$. In both fishing years, the USA allocations provided for an anticipated recreational harvest of 2,000 tons.

\section{Biology}

The most important spawning grounds in the Georges Bank-Gulf of Maine area are on eastern Georges Bank, although in some years significant spawning has also occurred in the Nantucket ShoalsGreat South Channel region (Walford, 1938; Bigelow and Schroeder, 1953; Posgay and Marak, 1970; Colton and St. Onge, 1974). Some spawning is also known to occur northward along the Maine coast (Bigelow and Schroeder, 1953; Grosslein, 1962). Depth of spawning, based on collections of spawning adults, varies from 28 to $110 \mathrm{~m}$ (R. Livingstone, Northeast Fisheries Center, pers. comm., March 1980).

Georges Bank haddock spawn between January and June, with peak activity usually during late March-April (Bigelow and Schroeder, 1953), although bottom temperatures may delay or advance this peak by a month or more (Marak and Livingstone, 1970). Individual females may produce up to 3 million eggs depending upon size (Livingstone, pers. comm., March 1980). Eggs are planktonic, ranging from 1.2 to $1.7 \mathrm{~mm}$ in diameter, and hatch in about 13 days at $5^{\circ} \mathrm{C}$; absorption of the yolk sac requires 10 days at this temperature (Bigelow and Schroeder, 1953). Survival prior to hatching appears to be highest when the temperature range is $4^{\circ}$ to $10^{\circ} \mathrm{C}$ (Laurence and Rogers, 1976). That study indicated that haddock embryos are less tolerant of temperature and salinity extremes than cod embryos. Laurence et al. (1981) observed that, in direct feeding competition studies, growth and survival rates of cod larvae were superior to those of haddock. Laurence (1974) also found that haddock larvae may have a critical period after hatching when mortality may be great depending on the availability of planktonic prey.

Juveniles are pelagic in habit for several months (Colton and Temple, 1961; Colton, 1965), the phase

\footnotetext{
"Optimum yield" of a fishery is defined as the amount of fish (a) that will provide the greatest overall benefit to the nation (USA) with particular reference to food production and recreational opportunities, and (b) which is prescribed as such on the basis of the maximum sustainable yield from such fishery, as modified by any relevant economic, social or ecological factors. (Fishery Conservation and Management Act of 1976; US Public Law 94-265; 94th Congress, H. R. 200, April 13, 1976).
} 
possibly extending into winter, as they do not appear to be fully available to capture by bottom-trawl survey gear until the following spring. Little is known about the pelagic phase of the life cycle, although Colton and Temple (1961) reported a close association between juvenile haddock and the common red jellyfish, Cyanea sp., and Bigelow and Schroeder (1953) indicated that they feed on planktonic crustaceans. Subsequently, juveniles settle to the bottom, where they remain for the rest of their lives. Small invertebrates, especially echinoderms, crustaceans and annelid worms constitute the bulk of the diet during the demersal phase of the life span (Wigley, 1956; Wigley and Theroux, 1965; Maurer and Bowman, MS 1975).

In maturation studies of Georges Bank haddock, Clark (1959) found that $21 \%$ of age 2 and $88 \%$ of age 3 fish were sexually mature, based on limited sampling during 1949-50. In more recent studies, Livingstone (pers. comm., March 1980) found that $46 \%$ of all age 2 haddock ( $64 \%$ male, $28 \%$ female) and $83 \%$ of all age 3 fish ( $90 \%$ male, $76 \%$ female) examined during 1968-72 were sexually mature and that the percentages subsequently increased to $54 \%$ for age 2 fish ( $74 \%$ male, $34 \%$ female) and to $95 \%$ for age 3 fish (98\% male, $92 \%$ female) based on sampling during 1973-75.

\section{Stock Structure}

The Georges Bank haddock population (east of the Great South Channel, Fig. 1) appears to be relatively isolated from other areas. Early tagging studies (Needler, 1930; Schroeder, 1942; Grosslein, 1962), age composition and growth data (Needler, 1930; Schuck and Arnold, 1951), and meristic (vertebral) data (Clark and Vladykov, 1960) indicated practically no interchange between Georges Bank and areas to the east. Needler (1930) concluded that "the deep water of the Fundian Channel and of the central basin of the Gulf of Maine forms an effective barrier separating the haddock of the New England region from those of the Nova Scotian region", which might be expected in that haddock are uncommon at depths exceeding 100 fathoms (183 m) (Bigelow and Schroeder, 1953). Later tagging studies (Halliday and McCracken, 1970) also indicated little interchange of haddock between Georges Bank and Gulf of Maine areas and western Nova Scotia waters, and USA bottom-trawl surveys for 1975-77 likewise indicate a more or less discontinuous distribution (Fig. 2). Previous tagging studies also indicated little interchange between Georges Bank and the Nantucket Shoals and Gulf of Maine areas (Schroeder, 1942; McCracken, 1960; Grosslein, 1962).

Stock structure in the Nantucket Shoals-Gulf of Maine region is less clear. Tagging data from early studies suggested haddock movements in these areas to be limited (Schroeder, 1942; Bigelow and
Schroeder, 1953). However, McCracken (1960), from tagging studies in Passamaquoddy Bay, found evidence for seasonal northward movement in the western Gulf of Maine in spring, followed by a reverse migration in early winter, and also evidence for some movement across the Bay of Fundy to western Nova Scotia. Small numbers of tagged haddock were also recaptured on Georges Bank. Grosslein (1962) hypothesized the existence of two somewhat distinct stocks in the western Gulf of Maine: a seasonally-migratory group (evidenced by McCracken's (1960) studies) ranging primarily from Jeffreys Ledge to the Bay of Fundy, and a relatively non-migratory group extending from Jeffreys Ledge to Nantucket Shoals. Grosslein also reported the existence of separate egg concentrations in the Great South Channel-Nantucket Shoals area and the western Gulf of Maine, although later ichthyoplankton data indicated a more or less continuous distribution (Colton and St. Onge, 1974). Early age composition and growth studies indicated a fairly close relationship between haddock of the Nantucket Shoals and Gulf of Maine areas (Needler, 1930). Bottom-trawl survey data for 1975-77 (Fig. 2) reveal only minor seasonal differences in distribution, indicating that haddock in these areas are relatively nonmigratory.

In summary, previous studies have indicated the existence of two or possibly three groups of haddock in the Georges Bank-Gulf of Maine region, a Georges Bank group and one or two groups in the Nantucket Shoals-western Gulf of Maine area. Available data do not permit evaluation of the degree of intermixing among these groups, but interchange between these areas and Georges Bank does not appear to be extensive. It is possible that some interrelationships exist between these groups, as Grosslein and Hennemuth (1973) found generally good agreement between yearclass size in the Georges Bank, Gulf of Maine and Browns Bank areas, i.e. the same year-classes have historically tended to be relatively strong or weak throughout the region, but discrepancies have been noted (e.g. the 1978 year-class was estimated to be strong on Georges Bank and weak in other areas). Although the apparent consistency may be attributable in part to uniform environmental conditions favoring or inhibiting larval survival, a more direct association (e.g. larval drift between areas) may also be involved. Trends in nominal catches and abundance indices for Georges Bank and the Gulf of Maine (discussed below) have also clcsely paralieled each other. In the absence of more definitive data, haddock in the Gulf of Maine (Div. 5Y) and in the area from Nantucket Shoals to eastern Georges Bank (Div. 5Z) have been considered separately in this paper. These have been the traditional areas used for statistical reporting and sampling since the early 1930 's, thereby facilitating use of the existing data base. 
SPRING
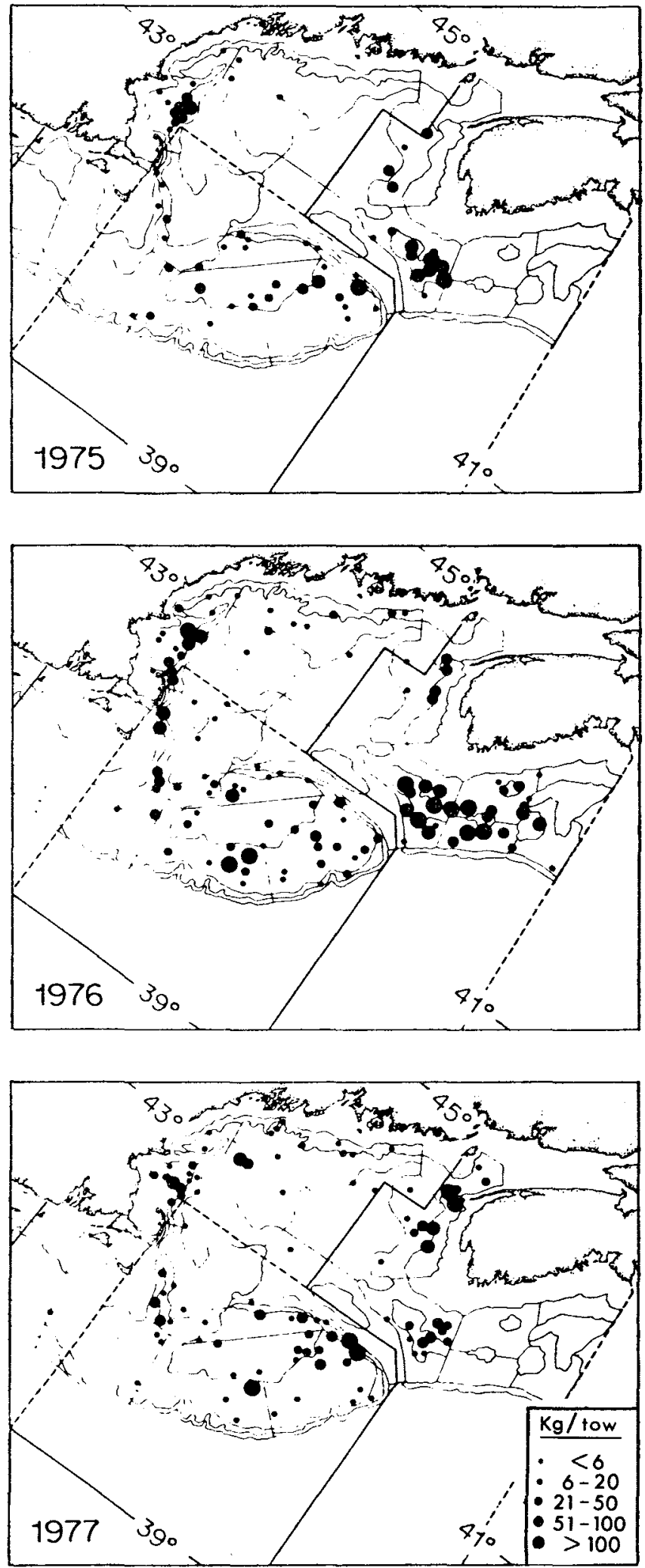

\section{AUTUMN}
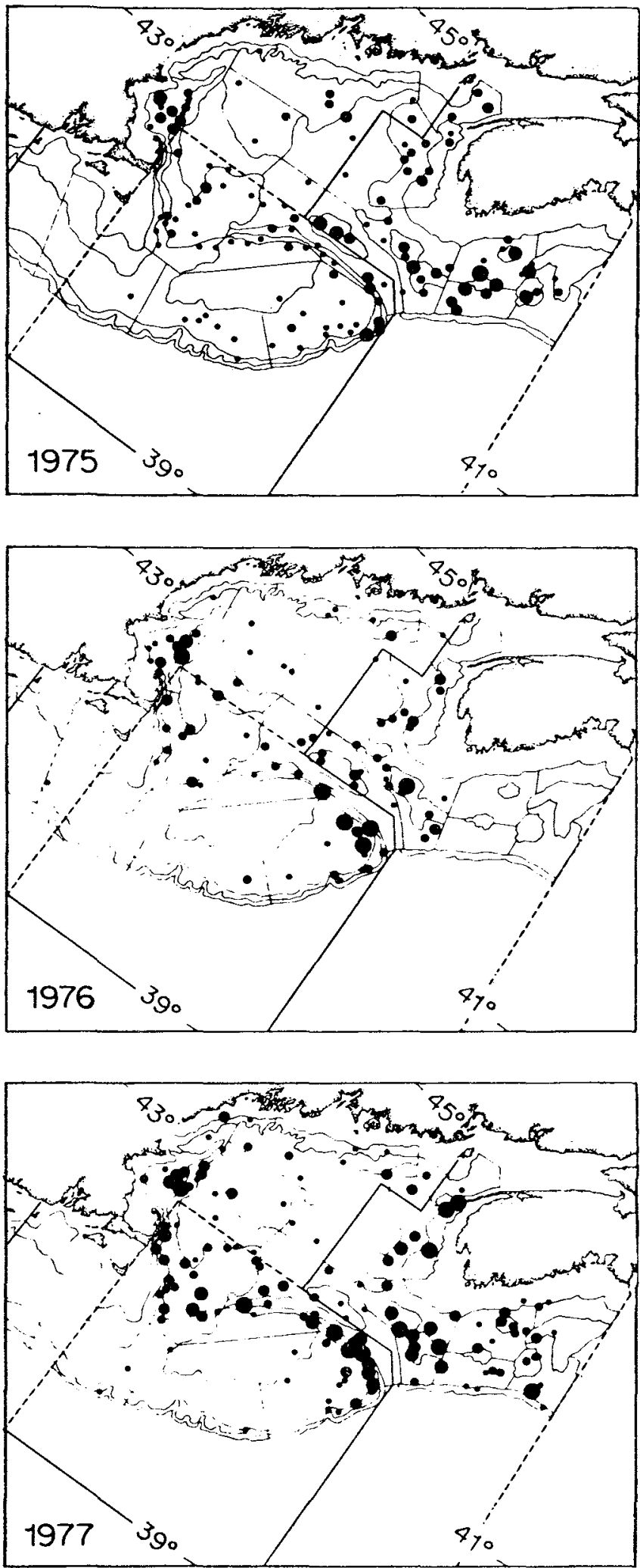

Fig. 2. Distribution of haddock (kg per tow) observed during USA spring and autumn bottom trawl surveys in Div. 4X and Subarea 5, 1975-77. 


\section{Commercial Fishery}

\section{Nominal catches}

Hennemuth (MS 1969) recognized three periods in the history of the Georges Bank haddock fishery. The first of these, from the early 1900's to the early 1930's, constituted a "developmental period" during which nominal catches increased rapidly in response to technological improvements in the industry and changes in consumer preference. Consequently, the Georges Bank catch increased to a peak of 115,500 tons in 1929 but subsequently decreased to about 26,000 tons in 1934 as declining catch rates led to a diversion of fishing effort to other areas and species. The fishery then entered a period of stability during $1935-60$, when fishing effort was relatively constant and catches averaged about 46,000 tons annually (Fig. 3). During these periods, the stock was exploited almost entirely by USA vessels.

The third period was marked by a rapid increase in fishing effort by distant-water (European) fleets and Canadian vessels, with a corresponding increase in haddock catches, followed by pronounced declines in abundance and productivity. The first catches by

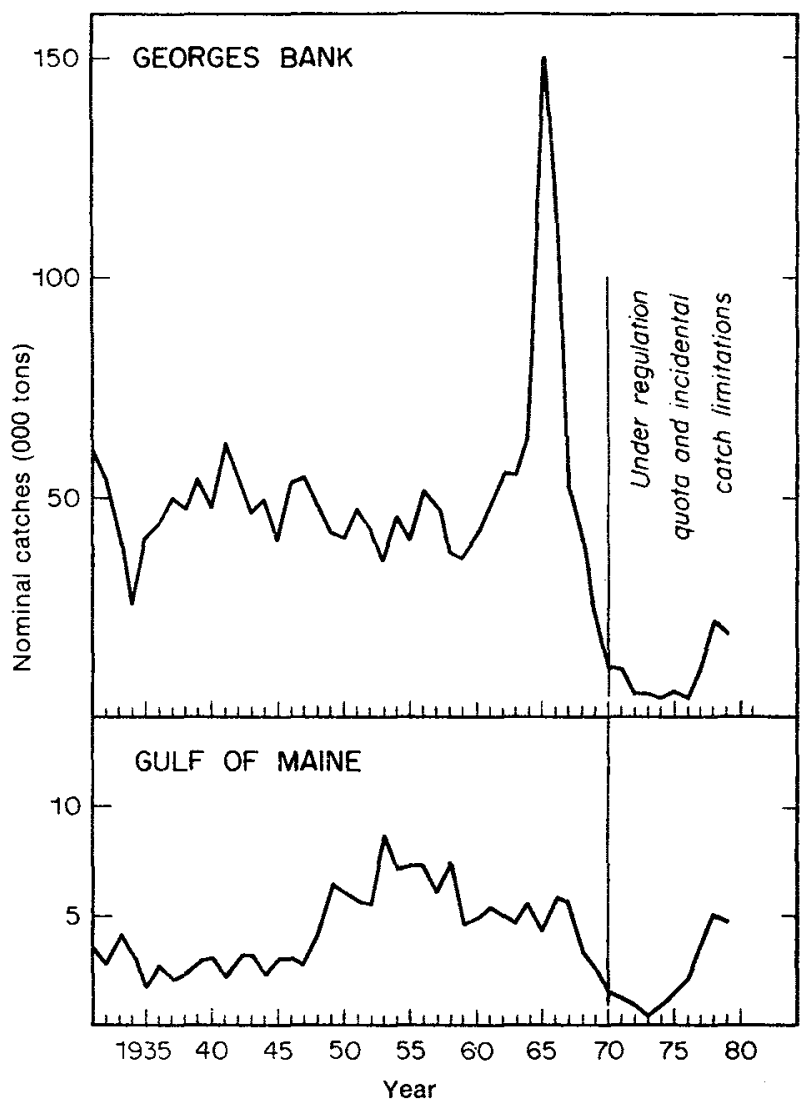

Fig. 3. Trends in nominal catches of haddock from Georges Bank and Gulf of Maine areas, 1931-79. distant-water fleets were reported by Union of Soviet Socialist Republics (USSR) in 1962 (Table 1). In succeeding years of good recruitment and high abundance, the USSR catch increased to a peak of 81,900 tons in 1965 , declined to 48,400 tons in 1966 and dropped sharply thereafter as fishing effort was diverted towards herring, Clupea harengus, and mackerel, Scomber scombrus. The Canadian catch also increased rapidly in the early 1960 's to 18,300 tons in 1966 , and the USA catch increased from 40,800 tons in 1960 to an average of 52,900 tons in $1965-66$. Other

TABLE 1. Nominal catches (metric tons) of haddock from the Georges Bank and Gulf of Maine areas, $1956-79^{\mathrm{a}}$

$\begin{array}{ccccc}\text { Year USA } & \text { Canada USSR Spain Others } & \text { Total } \\ \text { Georges Bank } & \end{array}$

\begin{tabular}{rrrrrrr}
1956 & 51,144 & - & - & - & - & 51,144 \\
1957 & 48,561 & - & - & - & - & 48,561 \\
1958 & 37,322 & - & - & - & - & 37,322 \\
1959 & 36,051 & - & - & - & - & 36,051 \\
1960 & 40,800 & 77 & - & - & - & 40,877 \\
1961 & 46,384 & 266 & - & - & - & 46,650 \\
1962 & 49,409 & 3,461 & 1,134 & - & - & 54,004 \\
1963 & 44,150 & 8,379 & 2,317 & - & - & 54,846 \\
1964 & 46,512 & 11,625 & 5,483 & 2 & 464 & 64,086 \\
1965 & 52,823 & 14,889 & 81,882 & 10 & 758 & 150,362 \\
1966 & 52,918 & 18,292 & 48,409 & 1,111 & 544 & 121,274 \\
1967 & 34,728 & 13,040 & 2,316 & 1,355 & 30 & 51,469 \\
1968 & 25,469 & 9,323 & 1,397 & 3,014 & 1,720 & 40,923 \\
1969 & 16,456 & 3,990 & 65 & 1,201 & 540 & 22,252 \\
1970 & 8,415 & 1,978 & 103 & 782 & 22 & 11,300 \\
1971 & 7,306 & 1,630 & 374 & 1,310 & 242 & 10,862 \\
1972 & 3,869 & 609 & 137 & 1,098 & 20 & 5,733 \\
1973 & 2,777 & 1,563 & 602 & 386 & 3 & 5,331 \\
1974 & 2,396 & 462 & 109 & 764 & 559 & 4,290 \\
1975 & 3,989 & 1,358 & 8 & 61 & 4 & 5,420 \\
1976 & 2,904 & 1,361 & 4 & 46 & 9 & 4,324 \\
1977 & 7,934 & 2,909 & -- & - & - & 10,843 \\
1978 & 12,160 & 10,179 & - & - & - & 22,339 \\
1979 & 14,279 & 5,182 & - & - & - & 19,461 \\
\hline & & & -196 &
\end{tabular}

\begin{tabular}{rrrrrrr}
1956 & 7,278 & 29 & - & - & - & 7,307 \\
1957 & 6,141 & 25 & - & - & - & 6,166 \\
1958 & 7,082 & 285 & - & - & - & 7,367 \\
1959 & 4,497 & 163 & - & - & - & 4,660 \\
1960 & 4,541 & 383 & - & - & - & 4,924 \\
1961 & 5,297 & 112 & - & - & - & 5,409 \\
1962 & 5,003 & 107 & - & - & - & 5,110 \\
1963 & 4,742 & 3 & 44 & - & - & 4,789 \\
1964 & 5,383 & 70 & - & - & - & 5,453 \\
1965 & 4,204 & 159 & - & - & - & 4,363 \\
1966 & 4,579 & 1,125 & - & - & - & 5,704 \\
1967 & 4,907 & 589 & - & - & - & 5,496 \\
1968 & 3,437 & 120 & - & - & - & 3,557 \\
1969 & 2,423 & 59 & - & 230 & 1 & 2,713 \\
1970 & 1,457 & 38 & - & 63 & 4 & 1,562 \\
1971 & 1,194 & 85 & - & 26 & 1 & 1,306 \\
1972 & 909 & 23 & 4 & - & - & 936 \\
1973 & 509 & 49 & - & - & - & 558 \\
1974 & 622 & 198 & - & - & 9 & 829 \\
1975 & 1,180 & 79 & - & 4 & - & 1,263 \\
1976 & 1,865 & 91 & - & - & - & 1,956 \\
1977 & 3,296 & 26 & - & - & - & 3,322 \\
1978 & 4,538 & 641 & - & - & - & 5,179 \\
1979 & 4,622 & 257 & - & - & - & 4,879 \\
\hline
\end{tabular}

* Data source: ICNAF (1958-80) and NAFO (1981).

- Bulgaria, Cuba, Federal Republic of Germany, France, German Democratic Republic, Ireland, Japan, Poland, Romania and United Kingdom. 
countries reporting catches of haddock from Georges Bank during the 1960's and 1970's, in addition to Spain (Table 1), were Bulgaria, Cuba, Federal Republic of Germany, France, German Democratic Republic, Ireland, Japan, Poland, Romania and United Kingdom. The Canadian and USA fisheries were directed towards haddock prior to 1974, and the USSR also directed substantial effort towards haddock in the mid1960 's, but catches by other countries appear to have been primarily incidental. Spanish catches resulted from demersal pair-trawling operations directed towards cod, and catches by Poland, Romania and USSR after 1966 resulted mainly from trawling operations directed towards herring, mackerel and silver hake, Merluccius bilinearis. The total nominal catch of Georges Bank haddock peaked at 150,400 tons in 1965 and then declined to 22,300 tons in 1969 (Fig. 3, Table 1) due to poor recruitment and declining abundance. The total catch averaged 11,100 tons in 1970-71 under a TAC of 12,000 tons, 5,500 tons in 1972-73 under a TAC of 6,000 tons and 4,700 tons in 1974-76 under incidental catch limitations. The catch subsequently increased to 22,300 tons in 1978 and 19,500 tons in 1979 , due primarily to recruitment and growth of the 1975 year-class. Only Canada and USA have reported catches of haddock from Georges Bank since 1976.

For the Gulf of Maine, nominal catches averaged over 10,000 tons annually during $1928-30$, declined to a relatively constant level of about 3,000 tons during 1931-47 and increased to an average of 7,300 tons annually during 1953-58 (Fig. 3, Table 1). The catch varied between 4,400 tons and 5,700 tons during 1959-67, declined to less than 600 tons by 1973 , and subsequently increased to about 5,000 tons during 1978-79. Gulf of Maine haddock were exploited exclusively by USA vessels until the mid-1950's when Canada began to report small catches from the area. Occasional catches by other countries have also been small.

\section{Age composition of catches}

Length frequencies and age-length keys were available for the USA haddock fishery on Georges Bank for 1931-79. Methods of sampling, ageing and analysis of such data were described by Hennemuth et al. (1964). Estimates of age compositions for 1931-55 were calculated on the basis of a biological year (February to January), and those for 1956-79 were derived by calendar year (Table 2 ).

For 1931-59, when the fishery was conducted entirely by USA vessels, monthly length frequencies were adjusted to provide length compositions of the corresponding nominal catches. These were then combined for 3-month periods (quarters) and the appropriate age-length keys applied to give quarterly catch-at-age compositions which were combined further to provide the estimated annual age composition of the catch. For later years, length frequencies and age-length keys were often unavailable for catches by Canada and distant-water fleets, and different procedures were used to estimate annual age compositions depending on whether catches were made with regulation-mesh groundfish trawls (i.e. Canada, Spain, United Kingdom and Ireland) or with small-mesh trawls (e.g. USSR). For the former group, USA quarterly catch-at-age compositions, obtained as described above, were adjusted upward using the appropriate nominal catches and then combined to provide the overall annual age composition of the catch for all countries involved. This procedure is not believed to have resulted in appreciable error, as catches by these countries were taken in essentially the same area as USA catches with trawls of similar (regulation) mesh-size. Available Canadian lengthfrequency data were generally similar to USA data, corroborating the validity of the procedure. For 1975 and 1976, when USA length-frequency data were limited in the last two quarters of the year, Canadian data (if available) were utilized together with USA data to calculate quarterly age compositions prior to their combination on an annual basis.

Nominal catches by the remaining countries (primarily USSR, Romania and Poland) appear to have been taken almost exclusively by small-mesh gear (i.e. trawls with 40-mm mesh codend liners), which necessitated a somewhat different aproach for years and seasons when sampling data were unavailable. USSR length frequencies, USA surveillance reports, information provided by USA fishermen, and USA research vessel survey data (Hennemuth, MS 1968) indicated that a large proportion of distant-water fleet catches during 1965 and 1966 consisted of ages 2 and 3 haddock. The basis for the method used was provided by USSR length frequencies of catches in the spring of 1973 and USA bottom-trawl survey data for April of that year, which were utilized to calculate a retention curve (Pope et al., 1975) for USSR trawls relative to the USA survey trawl. This curve was applied to length frequencies from USA spring, summer and autumn surveys, as appropriate, to estimate length frequencies of catches by USSR and "other" countries (Table 1) for 1963-76. Catch-at-age compositions were then estimated by applying these frequencies and USA age-length keys to the reported catches by quarter, and combining over quarters, as before. Exceptions to this procedure included the use of USA commercial sampling data (in the absence of USA survey data) to estimate the age composition of USSR catches in 1962, and the use of available USSR length frequencies for 1966 and 1973 with the application of USA age-length keys to obtain the age compositions of distant-water fleet catches in those years. 
TABLE 2. Estimated age composition of haddock in commercial landings (all countries) from Georges Bank (Div. 5Z), $1931-79$.

\begin{tabular}{|c|c|c|c|c|c|c|c|c|c|c|c|c|c|}
\hline \multirow[b]{2}{*}{ Year } & \multicolumn{10}{|c|}{ Number of fish caught (thousands) } & \multirow{2}{*}{$\begin{array}{c}\text { Nominal } \\
\text { catch } \\
\text { (tons) }\end{array}$} & \multirow{2}{*}{$\begin{array}{c}\text { Calculated } \\
\text { weight }^{\text {b }} \\
\text { (tons) }\end{array}$} & \multirow{2}{*}{$\begin{array}{c}\text { Ratio } \\
\text { Nom./ } \\
\text { Calc. }\end{array}$} \\
\hline & 1 & 2 & 3 & 4 & 5 & 6 & 7 & 8 & $9+$ & Total & & & \\
\hline $1931^{a}$ & 1,755 & 8,801 & 2,041 & 5,785 & 9,100 & 6,045 & 3,380 & 1,794 & 559 & 39,260 & 59,486 & 59,739 & 1.00 \\
\hline 1932 & 118 & 2,084 & 25,871 & 2,421 & 3,676 & 2,894 & 1,320 & 664 & 391 & 39,439 & 54,512 & 54,552 & 1.00 \\
\hline 1933 & 244 & 8,476 & 6,023 & 10.046 & 2,092 & 1.579 & 1,210 & 538 & 647 & 30.855 & 42,215 & 42,161 & 1.00 \\
\hline 1934 & 341 & 4,454 & 5,414 & 3,734 & 3,149 & 1,051 & 619 & 250 & 168 & 19,180 & 25,795 & 25,590 & 1.01 \\
\hline 1935 & 1,197 & 11,872 & 8,819 & 3,706 & 2,944 & 2,458 & 499 & 442 & 109 & 32,046 & 40.944 & 40,588 & 1.01 \\
\hline 1936 & 880 & 12,327 & 11,486 & 5,431 & 2,141 & 1,377 & 1,362 & 259 & 124 & 35,387 & 43,445 & 43,428 & 1.00 \\
\hline 1937 & 1,288 & 11,034 & 10.910 & 5,629 & 4,143 & 1,875 & 952 & 481 & 222 & 36,534 & 49,359 & 49,402 & 1.00 \\
\hline 1938 & 1,030 & 20.199 & 7,755 & 3,755 & 2,113 & 1,600 & 945 & 327 & 173 & 37,897 & 47,773 & 47,691 & 1.00 \\
\hline 1939 & 607 & 13,937 & 19,617 & 5,163 & 2,152 & 967 & 837 & 326 & 239 & 43,845 & 54,054 & 54,058 & 1.00 \\
\hline 1940 & 2,040 & 7,254 & 12,317 & 8,253 & 2,510 & 1,479 & 752 & 222 & 136 & 34,963 & 47,906 & 47,913 & 1.00 \\
\hline 1941 & 780 & 23,464 & 9,808 & 8,033 & 5,764 & 1,781 & 941 & 307 & 384 & 51,262 & 62,944 & 62,980 & 1.00 \\
\hline 1942 & 310 & 14,307 & 16,348 & 6,531 & 3,996 & 2,331 & 1,036 & 227 & 176 & 45,262 & 55,376 & 55,409 & 1.00 \\
\hline 1943 & 19 & 4,191 & 17,738 & 8,364 & 3,102 & 2,693 & 790 & 354 & 178 & 37,429 & 46,323 & 46,376 & 1.00 \\
\hline 1944 & 64 & 761 & 8,437 & 14,843 & 5,689 & 2,281 & 497 & 469 & 108 & 33,149 & 49,637 & 49,667 & 1.00 \\
\hline 1945 & 121 & 8,522 & 2,029 & 6,386 & 5,795 & 2,315 & 914 & 265 & 205 & 26,552 & 40,473 & 40,443 & 1.00 \\
\hline 1946 & 209 & 7,466 & 15,213 & 2738 & 5,785 & 3,840 & 1,827 & 272 & 23 & 37,373 & 53,719 & 53,683 & 1.00 \\
\hline 1947 & 90 & 16,621 & 10.334 & 7,181 & 2,127 & 2,739 & 1,501 & 745 & 457 & 41,795 & 54,431 & 54,376 & 1.00 \\
\hline 1948 & 80 & 11,227 & 19,237 & 5,116 & 2,744 & 1.157 & 780 & 450 & 369 & 41,160 & 48,360 & 48,303 & 1.00 \\
\hline 1949 & 328 & 6,472 & 12,479 & 9,608 & 2,347 & 1.061 & 624 & 409 & 353 & 33,681 & 42,254 & 42,500 & 0.99 \\
\hline 1950 & 88 & $28,97 \dagger$ & 4,107 & 4,272 & 3,315 & 1,131 & 520 & 225 & 250 & 42,879 & 41,273 & 41,255 & 1.00 \\
\hline 1951 & 645 & 8,266 & 26,472 & 2,177 & 2,448 & 2,138 & 740 & 297 & 215 & 43,398 & 47,318 & 47,422 & 1.00 \\
\hline 1952 & - & 25,120 & 8,892 & 8,485 & 1,361 & 944 & 530 & 182 & 107 & 45,621 & 43,252 & 43,349 & 1.00 \\
\hline 1953 & 1,083 & 1,807 & 17,588 & 5,726 & 3,757 & 1,012 & 542 & 337 & 152 & 32,004 & 35,926 & 35,930 & 1.00 \\
\hline 1954 & 108 & 31,858 & 5,107 & 5,611 & 2,315 & 2,131 & 720 & 353 & 98 & 48,301 & 46,388 & 46,401 & 1.00 \\
\hline 1955 & 90 & 3,941 & 19,251 & 3,316 & 3,278 & 1,649 & 1,068 & 320 & 173 & 33,086 & 40,851 & 40,881 & 1.00 \\
\hline 1956 & 52 & 11,948 & 6,698 & 12,066 & 3,405 & 3,378 & 1,348 & 563 & 201 & 39,659 & 51,144 & 52,284 & 0.98 \\
\hline 1957 & 35 & 6,594 & 14,046 & 4,523 & 5,822 & 2,357 & 1,630 & 473 & 366 & 35,846 & 48,561 & 48,847 & 0.99 \\
\hline 1958 & 125 & 5,571 & 7,088 & 6,665 & 3.784 & 2,366 & 903 & 442 & 142 & 27,086 & 37,322 & 37,761 & 0.99 \\
\hline 1959 & 94 & 5,716 & 7.994 & 5,169 & 3,934 & 1,758 & 1,172 & 424 & 334 & 26,595 & 36,051 & 37,994 & 0.95 \\
\hline 1960 & 258 & 16,010 & 6,122 & 4,562 & 3,067 & 1,792 & 787 & 406 & 348 & 33,352 & 40,877 & 42,930 & 0.95 \\
\hline 1961 & 62 & 10,689 & 14,927 & 4,198 & 2,917 & 1,856 & 1,266 & 496 & 674 & 37,085 & 46,650 & 48,522 & 0.96 \\
\hline 1962 & 74 & 4,455 & 16,245 & 10,440 & 3,448 & 2,089 & 1,566 & 1,185 & 898 & 40,400 & 54,004 & 56,430 & 0.96 \\
\hline 1963 & 2,910 & 4,047 & 7,418 & 11,152 & 8,198 & 2,205 & 1,405 & 721 & 1,096 & 39,152 & 54,846 & 57,731 & 0.95 \\
\hline 1964 & 10,101 & 15,935 & 4,554 & 4,776 & 8,722 & 5,794 & 2,082 & 1,028 & 1,332 & 54,324 & 64,086 & 67,823 & 0.94 \\
\hline 1965 & 9,601 & 125,818 & 44,496 & 5,356 & 4,391 & 6,690 & 3,772 & 1,094 & 1,366 & 202,584 & 150,362 & 181,774 & 0.83 \\
\hline 1966 & 114 & 6,843 & 100,810 & 19,167 & 2,768 & 2,591 & 2,332 & 1,268 & 867 & 136,760 & 121,274 & 140,715 & 0.86 \\
\hline 1967 & 1,150 & 168 & 2,891 & 20,667 & 10,338 & 1,209 & 993 & 917 & 698 & 39,031 & 51,469 & 52,065 & 0.99 \\
\hline 1968 & 8 & 2,994 & 709 & 1,921 & 14,519 & 3,499 & 677 & 453 & 842 & 25,622 & 40,923 & 41,018 & 1.00 \\
\hline 1969 & 2 & 11 & 1,698 & 448 & 654 & 5,954 & 1,574 & 225 & 570 & 11,136 & 22,252 & 22,336 & 1.00 \\
\hline 1970 & 46 & 158 & 16 & 570 & 186 & 214 & 2,308 & 746 & 464 & 4,708 & 11,300 & 12,376 & 0.91 \\
\hline 1971 & - & 1,375 & 223 & 40 & 289 & 246 & 285 & 1,469 & 928 & 4,855 & 10,862 & 11,998 & 0.91 \\
\hline 1972 & 156 & 2 & 450 & 81 & 32 & 120 & 78 & 66 & 1,236 & 2,221 & 5,733 & 6,464 & 0.89 \\
\hline 1973 & 2,560 & 2,057 & 3 & 386 & 53 & 30 & 77 & 15 & 447 & 5,628 & 5.331 & 6,790 & 0.79 \\
\hline 1974 & 46 & 1,820 & 657 & 2 & 70 & 2 & 2 & 53 & 249 & 2,901 & 4,290 & 4,647 & 0.92 \\
\hline 1975 & 192 & 1,034 & 1,864 & 375 & 4 & 42 & 4 & 4 & 88 & 3,607 & 5,420 & 5,545 & 0.98 \\
\hline 1976 & 144 & 473 & 550 & 880 & 216 & - & 23 & 4 & 112 & 2,402 & 4,324 & 4,287 & 1.01 \\
\hline 1977 & - & 6,130 & 187 & 680 & 515 & 357 & 4 & 39 & 111 & 8,023 & 10,843 & 11,582 & 0.94 \\
\hline 1978 & - & 761 & 11,315 & 305 & 567 & 517 & 139 & 14 & 67 & 13,685 & 22,339 & 22,403 & 1.00 \\
\hline 1979 & - & 26 & 1,726 & 7,169 & 525 & 410 & 315 & 96 & 46 & 10,313 & 19,461 & 21,100 & 0.92 \\
\hline
\end{tabular}

a Lata for 1931-55 reported in terms of "biological year" (February-January); data for 1956-79 reported by calendar year.

- Obtained by multiplying numbers caught at age by corresponding mean weight-at-age data in Table 7.

The age compositions of catches assumed to have been taken by small-mesh trawls were combined with those taken by large-mesh (regulation) trawls to obtain the age compositions of total nominal catches by all countries for the 1931-79 period (Table 2, Fig. 4). Calculated catch weights, obtained by multiplying catchat-age values in Table 2 by corresponding mean weight-at-age values (Table 7 ) and summing over agegroups, were generally within $5 \%$ of the observed weights, the largest discrepancies being related to years when sampling inadequacies existed (e.g. 1965 and 1966). No attempt was made to incorporate recreational catches into the data base for Georges Bank, as nearly all of these haddock were taken in the western Gulf of Maine.

About $80 \%$ of the haddock (numbers) landed from Georges Bank during 1935-60 consisted of agegroups 2, 3 and 4 (Table 2, Fig. 4), the relative proportions being 32,31 and $17 \%$ respectively. Introduction of 


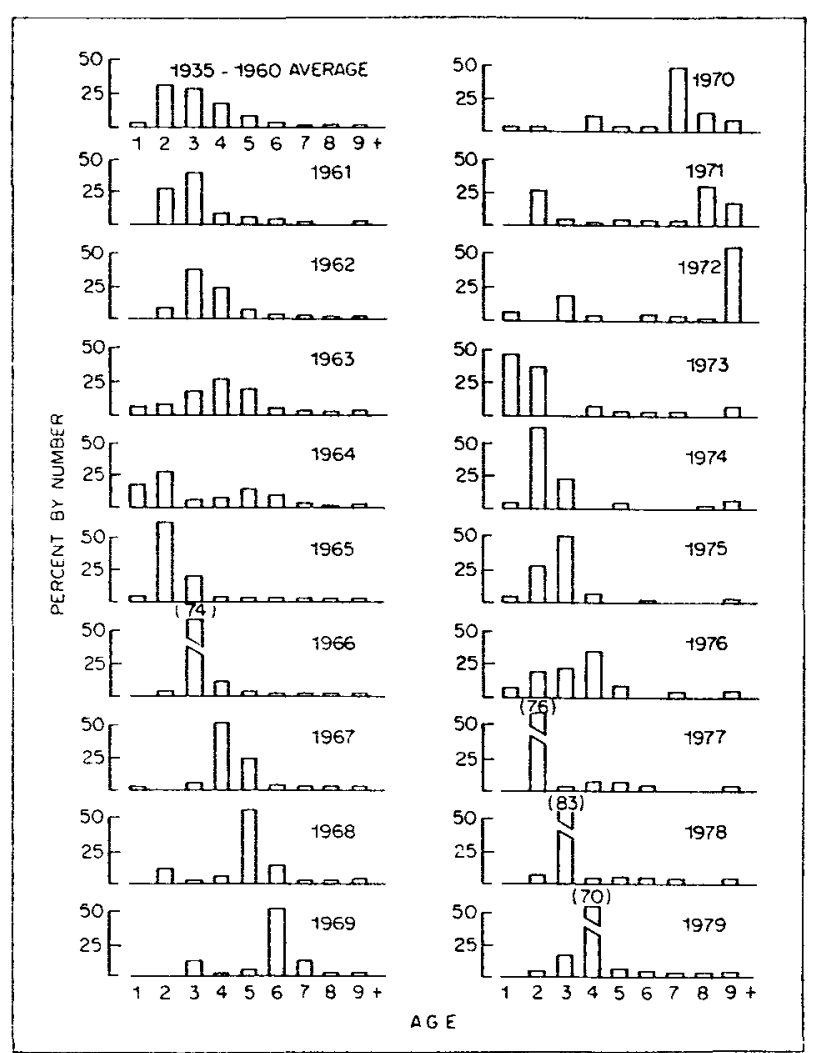

Fig. 4. Percentage age composition of haddock in commercial landings from Georges Bank, combined for 1935-60 and individually for 1961-1979.

the mesh regulation in 1953, specifying 4.5 inches ( 114 $\mathrm{mm}$ ) as the minimum codend mesh size, markedly reduced the catching and discarding of unmarketable haddock (Graham and Premetz, 1955). However, because the $50 \%$ selection length for $114-\mathrm{mm}$ mesh trawls $(37.5 \mathrm{~cm})$ closely approximated the average cull size $(34-35 \mathrm{~cm})$ in those years, there was little observable change in the age composition of commercial landings following the introduction of the mesh regulation, and short-term losses were minimal. Recruitment of the outstanding 1963 year-class in 1965, heavy exploitation during 1965-66, and poor recruitment in subsequent years resulted in a significant change in age composition; for example, the 1963 year-class accounted for 62 and $74 \%$ of the haddock catch (numbers) in 1965 and 1966 respectively. This yearclass accounted for $65 \%$ of the total number and $54 \%$ of the total weight caught during 1965-69 and continued to support the fishery during the early 1970's in the absence of significant contributions from the relatively poor year-classes of 1965-71 (Table 2, Fig. 4). The 1972 year-class, although weak, was considerably larger than the 1965-71 year-class average and provided a relatively large catch (number) of age 1 fish in 1973 (Fig. 4), taken primarily by USSR vessels. Recruitment of the 1971 and 1972 year-classes had a depressing effect on the percentage of total catch by number accounted for by the 1963 year-class, but this yearclass still accounted for over $25 \%$ of the nominal catch by weight during 1973-74. The strong 1975 year-class, which recruited to the fishery in 1977, accounted for $76 \%$ of the catch by number and $69 \%$ by weight during 1977-79 (Table 2, Fig. 4).

Age composition data for the Gulf of Maine commercial fishery are comparatively limited, but available information indicates that age-structure and recruitment patterns in recent years (not illustrated) were generally similar to those observed for Georges Bank. The 1963 year-class contributed the bulk of the catch by number and weight during 1966-70, and the 1975 year-class predominated during 1977-79. Intervening years were characterized by poor recruitment, as was the case for Georges Bank.

\section{Recreational Fishery}

Information on recreational catches of haddock in the New England area was collected in national saltwater angling surveys for 1960, 1965 and 1970 (Clark, 1962; Deuel and Clark, 1968; Deuel, 1973), in a regional survey of northeastern United States for 1974 (Ridgely and Deuel, MS 1976), and in a marine recreational fishery statistics survey of the Atlantic and Gulf coasts for 1979 (U.S. Dept. Commerce, 1980). Nicholson and Ruais (MS 1979) also derived estimates of recreational catches by party and charter boats in the Georges Bank-Gulf of Maine region for 1978 by analysis of logbook data, but reporting was incomplete and the catches appear to have been underestimated to an unknown degree. The first three surveys were conducted by household interviews soliciting data on number and average weight of each species caught over a recall period of one year. The 1974 survey collected similar information by telephone and by mail for a 2-month recall period. The 1979 survey included telephone interviews to obtain trip data over a 2-month recall period and on-site interviews during which catches were sampled to determine species and size composition. Differences in methodology and regional boundaries imply that results are comparable only in a general way. The 1-year recall period used in earlier surveys implies the potential for overestimation (U.S. Dept. Commerce, 1980).

The 1960,1965 and 1970 surveys indicated recreational haddock catches of $767,9,702$ and 1,147 tons respectively, but the 1974 survey indicated a catch of only 199 tons. Party and charter-boat logbook data for 1978 indicated a catch of 279 tons, but, as that segment of the fishery accounted for only $70 \%$ of the total recreational catch of haddock in 1970 (Deuel, 1973), the total recreational catch in 1978 probably exceeded 400 tons. The bulk of the reported catch in 1978 was taken in late autumn and practically the entire amount 
(278 tons) was taken in the western Gulf of Maine. Results of the 1979 survey indicated a total recreational haddock catch of 406 tons. Even in the western Gulf of Maine, however, haddock seems to be of relatively minor importance as a recreational species; cod and pollock accounted for $90 \%$ of Maine party-boat catches in 1977 (Nicholson and Ruais, MS 1979).

\section{Research Vessel Surveys}

Research vessels of the Northeast Fisheries Center, Woods Hole, have conducted bottom-trawl surveys of the Georges Bank-Gulf of Maine area in autumn since 1963 and in spring since 1968. A stratifiedrandom sampling design has been used for these surveys based on geographical strata delineated by depth and historical fishing patterns (Fig. 5). A standard " 36 Yankee" groundfish trawl with 1.25-cm mesh codend liner was used in all autumn surveys and in all spring surveys during 1968-72; a modified high-opening "41 Yankee" trawl was used in subsequent spring surveys, and consequently data for 1968-72 were adjusted by a factor of 1.7 to compensate for differences in surface area covered by the two different trawls. Details of survey procedures and application of resulting data to stock assessments have been published elsewhere (Grosslein, 1969; Clark, 1979). The data from these surveys have been used in this paper to derive indices of relative abundance and biomass (stratified mean catch per tow in numbers and weight) and to evaluate mortality, growth and recruiting year-class size.

\section{Trends in abundance and biomass}

The spring survey (weight) index for Georges Bank (Fig. 5, strata 13-25, 29 and 30) declined from $23.1 \mathrm{~kg}$ in 1968 to $5.4 \mathrm{~kg}$ in 1975 and subsequently increased to $35.7 \mathrm{~kg}$ in 1980, the highest value observed in this time series (Table 3). The corresponding autumn survey index declined from $64.1 \mathrm{~kg}$ in 1964 to $2.6 \mathrm{~kg}$ in 1974, increased to an average of $23.4 \mathrm{~kg}$ in 1976-77, and varied from 15.2 to $26.9 \mathrm{~kg}$ during $1978-80$, the average being $20.2 \mathrm{~kg}$. Trends in spring and autumn survey indices in terms of numbers have closely paralleled those observed in terms of weight (Table 3). These data indicate a decline in biomass of more than $90 \%$ during 1964-74, and spawning stock, as evidenced by catches of age 3 and older haddock in spring and age 2 and older haddock in autumn (Tables 4 and 5), declined to an apparent all-time low during the early 1970's. Increased abundance and biomass in

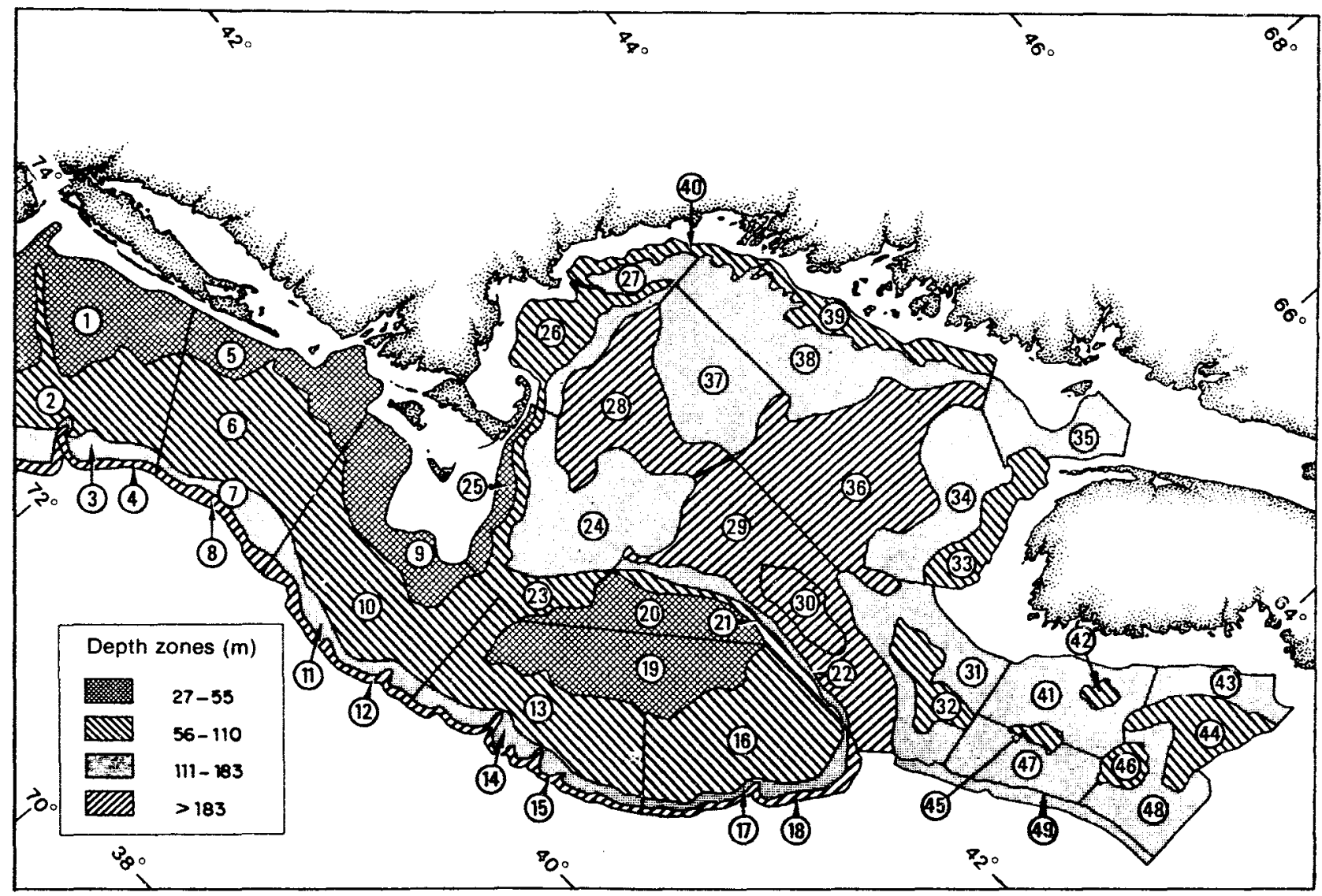

Fig. 5. Stratification scheme used for USA spring and autumn bottom-trawl surveys of Georges Bank and Gulf of Maine areas. 
TABLE 3. Mean catch per tow in numbers and weight $(\mathrm{kg})$ of haddock in spring and autumn stratified-random bottom-trawl surveys on Georges Bank and in the Gulf of Maine, 1963-80.

\begin{tabular}{|c|c|c|c|c|c|c|c|c|}
\hline \multirow[b]{3}{*}{ Year } & \multicolumn{4}{|c|}{ Georges Bank ${ }^{\mathrm{a}}$} & \multicolumn{4}{|c|}{ Gulf of Maine } \\
\hline & \multicolumn{2}{|c|}{ Spring } & \multicolumn{2}{|c|}{ Autumn } & \multicolumn{2}{|c|}{ Spring } & \multicolumn{2}{|c|}{ Autumn } \\
\hline & Number & Weight & Number & Weight & Number & Weight & Number & Weight \\
\hline 1963 & - & - & 97.34 & 52.83 & - & - & 46.68 & 33.57 \\
\hline 1964 & - & - & 129.70 & 64.07 & - & - & 9.51 & 12.47 \\
\hline 1965 & - & - & 68.26 & 48.20 & - & - & 11.70 & 11.72 \\
\hline 1966 & - & - & 22.32 & 19.78 & - & - & 7.82 & 9.18 \\
\hline 1967 & - & - & 11.88 & 16.87 & - & - & 8.18 & $\$ 1.16$ \\
\hline 1968 & 15.56 & 23.13 & 5.06 & 10.20 & 6.99 & 9.71 & 5.75 & 11.42 \\
\hline 1969 & 8.26 & 19.05 & 2.28 & 5.59 & 4.32 & 8.30 & 3.66 & 8.51 \\
\hline 1970 & 6.84 & 19.28 & 5.17 & 8.94 & 1.03 & 1.94 & 1.96 & 4.87 \\
\hline 1971 & 3.18 & 5.62 & 2.83 & 3.70 & 1.00 & 2.84 & 1.93 & 5.39 \\
\hline 1972 & 7.26 & 8.30 & 7.62 & 5.61 & 0.98 & 0.98 & 1.33 & 2.01 \\
\hline 1973 & 25.23 & 10.18 & 9.98 & 6.48 & 0.88 & 1.06 & 2.80 & 5.68 \\
\hline 1974 & 12.77 & 11.72 & 2.71 & 2.64 & 0.96 & 0.70 & 1.80 & 2.21 \\
\hline 1975 & 4.18 & 5.44 & 20.78 & 10.00 & 1.86 & 2.30 & 3.71 & 5.71 \\
\hline 1976 & 55.83 & 10.41 & 47.68 & 23.68 & 5.59 & 4.21 & 4.05 & 5.32 \\
\hline 1977 & 24.74 & 17.60 & 19.02 & 23.13 & 4.56 & 4.45 & 6.79 & 7.34 \\
\hline 1978 & 13.03 & 20.71 & 20.70 & 15.18 & 0.91 & 0.95 & 8.00 & 18.16 \\
\hline 1979 & 30.53 & 13.09 & 42.74 & 26.87 & 2.32 & 3.17 & 4.52 & 11.50 \\
\hline 1980 & 40.32 & 35.71 & 24.98 & 18.47 & 1.81 & 2.24 & 5.85 & 8.24 \\
\hline
\end{tabular}

${ }^{a}$ Strata $13-25$ and $29-30$ of Fig. 5.

${ }^{\text {b }}$ Strata $26-28$ and $36-40$ of Fig. 5

TABLE 4. Age composition of haddock caught per tow in spring bottom-trawi surveys on Georges Bank and in the Gulf of Maine, 1968-80.

\begin{tabular}{|c|c|c|c|c|c|c|c|c|c|c|c|c|c|c|c|}
\hline \multirow[b]{2}{*}{ Year } & \multicolumn{12}{|c|}{ Mean catch per tow at age (numbers) } & \multicolumn{3}{|c|}{ Totals } \\
\hline & 1 & 2 & 3 & 4 & 5 & 6 & 7 & 8 & 9 & 10 & 11 & $12+$ & Age $1+$ & Age 2+ & Age 3+ \\
\hline \multicolumn{16}{|c|}{ Georges Bank } \\
\hline 1968 & 0.27 & 3.23 & 0.53 & 0.80 & 7.62 & 1.92 & 0.29 & 0.51 & 0.37 & - & - & - & $15.54^{a}$ & 15.27 & 12.04 \\
\hline 1969 & 0.02 & 0.05 & 0.66 & 0.17 & 0.48 & 4.83 & 1.17 & 0.32 & 0.15 & 0.17 & 0.10 & 0.10 & 8.22 & 8.20 & 8.15 \\
\hline 1970 & 0.77 & 0.29 & - & 0.37 & 0.53 & 0.53 & 2.28 & 1.12 & 0.54 & 0.14 & 0.22 & 0.07 & 6.86 & 6.09 & 5.80 \\
\hline 1971 & - & 1.33 & 0.29 & - & 0.14 & 0.14 & 0.10 & 0.94 & 0.20 & 0.03 & - & 0.03 & 3.20 & 3.20 & 1.87 \\
\hline 1972 & 4.61 & 0.10 & 0.70 & 0.14 & 0.03 & 0.05 & 0.15 & 0.03 & 0.97 & 0.29 & 0.10 & 0.12 & 7.29 & 2.68 & 2.58 \\
\hline 1973 & 20.59 & 3.25 & - & 0.36 & 0.06 & - & 0.12 & 0.01 & - & 0.66 & 0.05 & 0.15 & 25.25 & 4.66 & 1.41 \\
\hline 1974 & 1.43 & 8.92 & 1.92 & - & 0.16 & - & 0.01 & 0.07 & - & - & 0.16 & 0.09 & 12.76 & 11.33 & 2.41 \\
\hline 1975 & 0.63 & 0.65 & 2.23 & 0.42 & - & 0.09 & 0.06 & 0.01 & - & - & 0.01 & 0.09 & 4.19 & 3.56 & 2.91 \\
\hline 1976 & 54.22 & 0.20 & 0.40 & 0.62 & 0.29 & - & 0.03 & - & - & - & 0.01 & 0.06 & 55.83 & 1.61 & 1.41 \\
\hline 1977 & 0.41 & 22.42 & 0.28 & 0.82 & 0.40 & 0.30 & - & 0.03 & - & - & - & 0.08 & 24.74 & 24.33 & 1.91 \\
\hline 1978 & 0.05 & 0.65 & 10.69 & 0.24 & 0.63 & 0.55 & 0.11 & 0.04 & 0.02 & 0.02 & - & 0.03 & 13.03 & 12.98 & 12.33 \\
\hline 1979 & 24.24 & 1.06 & 0.76 & 3.83 & 0.22 & 0.11 & 0.25 & 0.04 & 0.02 & - & - & 0.01 & 30.54 & 6.30 & 5.24 \\
\hline 1980 & 3.49 & 31.34 & 0.34 & 0.70 & 3.27 & 0.45 & 0.25 & 0.31 & 0.10 & 0.06 & - & - & 40.31 & 36.82 & 5.48 \\
\hline
\end{tabular}

\section{Gulf of Maine}

\begin{tabular}{|c|c|c|c|c|c|c|c|c|c|c|c|c|c|c|c|}
\hline 1968 & - & - & - & 0.39 & 5.15 & 1.09 & 0.09 & 0.03 & 0.24 & - & - & - & $6.99^{a}$ & 6.99 & 6.99 \\
\hline 1971 & - & - & - & - & - & 0.03 & 0.03 & 0.73 & 0.05 & 0.05 & 0.05 & 0.05 & 0.99 & 0.99 & 0.99 \\
\hline 1972 & 0.66 & - & - & - & 一 & - & - & - & 0.24 & 0.03 & 0.02 & 0.02 & 0.97 & 0.31 & 0.31 \\
\hline 1974 & 0.60 & 0.06 & 0.22 & - & - & - & - & - & 0.01 & 0.01 & 0.01 & 0.06 & 0.97 & 0.37 & 0.31 \\
\hline 1975 & 0.01 & 1.32 & 0.10 & 0.25 & - & 0.01 & - & - & - & - & 0.01 & 0.16 & 1.86 & 1.85 & 0.53 \\
\hline 1976 & 3.46 & 0.05 & 1.24 & 0.12 & 0.61 & - & 0.02 & - & - & - & - & 0.09 & 5.59 & 2.13 & 2.08 \\
\hline 1979 & 0.25 & - & 1.08 & 0.80 & 0.06 & 0.08 & 0.06 & - & - & - & - & - & 2.33 & 2.08 & 2.08 \\
\hline 1980 & 0.87 & 0.12 & 0.14 & 0.36 & 0.28 & 0.02 & - & - & - & - & - & 0.03 & 1.82 & 0.95 & 0.83 \\
\hline
\end{tabular}

aifferences between values in this column and data in Table 3 are due to rounding. 
TABLE 5. Age composition of haddock caught per tow in autumn bottom-trawl surveys on Georges Bank and in the Gulf of Maine, 1963-80.

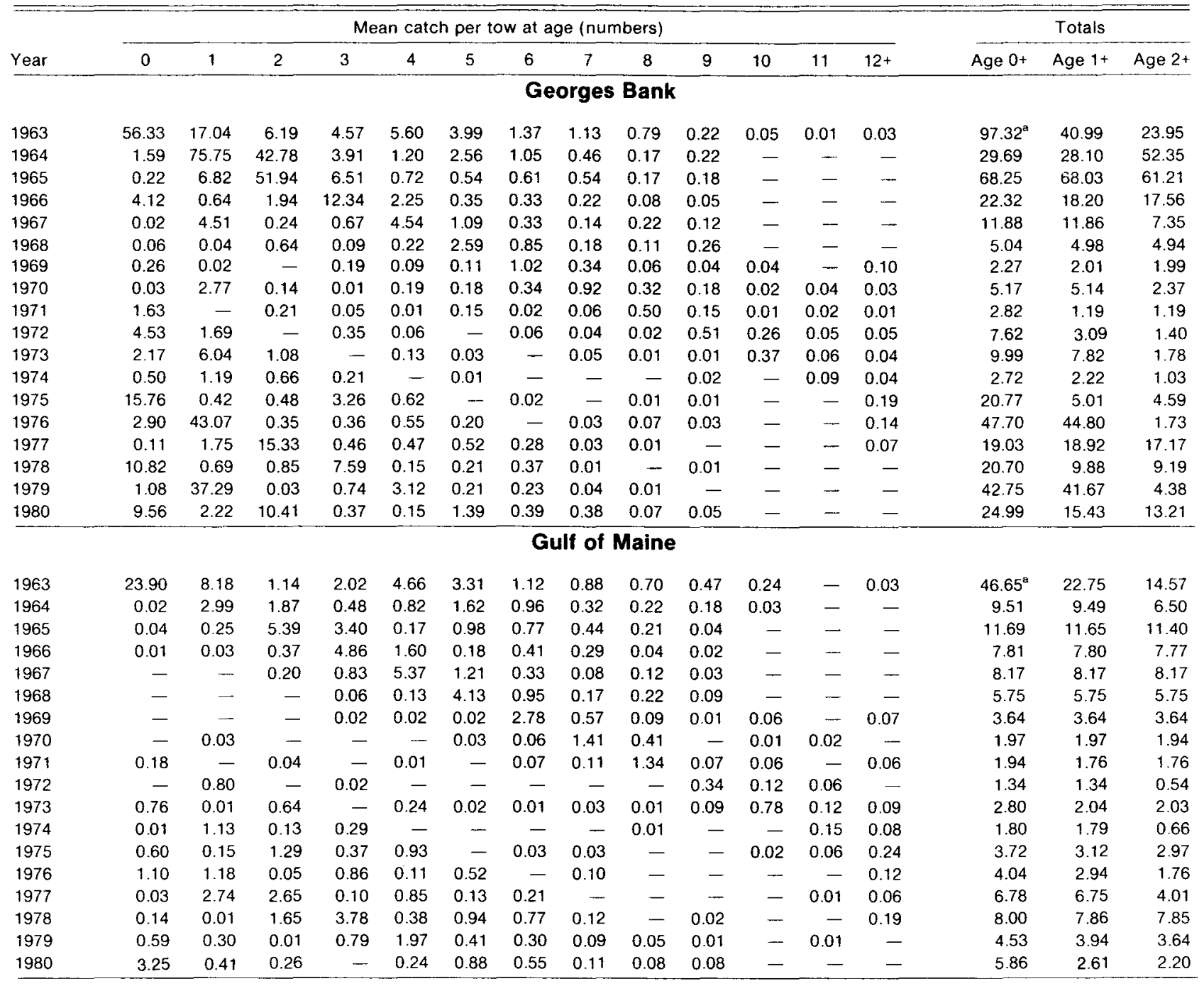

a Differences between values in this column and data in Table 3 are due to rounding.

the late 1970's primarily reflect recruitment and growth of the 1975 and 1978 year-classes (discussed below).

Trends in indices for the Gulf of Maine (Fig. 5, strata 26-28 and 36-40) are similar to those for Georges Bank (Table 3). The spring survey (weight) index declined from $9.2 \mathrm{~kg}$ in 1968 to $0.7 \mathrm{~kg}$ in 1974 , increased to $4.5 \mathrm{~kg}$ in 1977 and then declined to an average of $2.7 \mathrm{~kg}$ in 1979-80. The corresponding autumn survey index declined from $33.6 \mathrm{~kg}$ in 1963 to low values of $2.0 \mathrm{~kg}$ in 1972 and $2.2 \mathrm{~kg}$ in 1974 , increased to $18.2 \mathrm{~kg}$ in 1978 and then declined to an average of $9.9 \mathrm{~kg}$ in 1979-80. Again, trends in numbers per tow were similar (Table 3 ), and spawning stock size declined to minimal levels in the early 1970's (Tables 4 and 5).

Age distributions of haddock from these surveys indicate that the 1962 and 1963 year-classes dominated the Georges Bank and Gulf of Maine populations until the early 1970's (Tables 4 and 5). However, the 1975 and 1978 year-classes were the only strong yearclasses to appear on Georges Bank since 1963. The 1975 year-class accounted for $85 \%$ by number of the survey catch of age 2 and older fish in 1977-79, while the 1978 year-class accounted for 85 and $79 \%$ by number in the 1980 spring and autumn surveys respectively. The 1978 year-class appears to have been comparable in size to the 1975 year-class on Georges Bank but was obviously much weaker in the Gulf of Maine.

The pronounced changes in stock abundance evidenced by research vessel survey data have been accompanied by other changes as well. Spatial density, reflected by changes in relative frequericy of numbers caught per tow in autumn on Georges Bank (Fig. 6), has changed markedly, with declining percentages of large catch-per-tow values and a corresponding increase in percentages of small catches, as abundance declined in the late 1960's and early 1970's. 


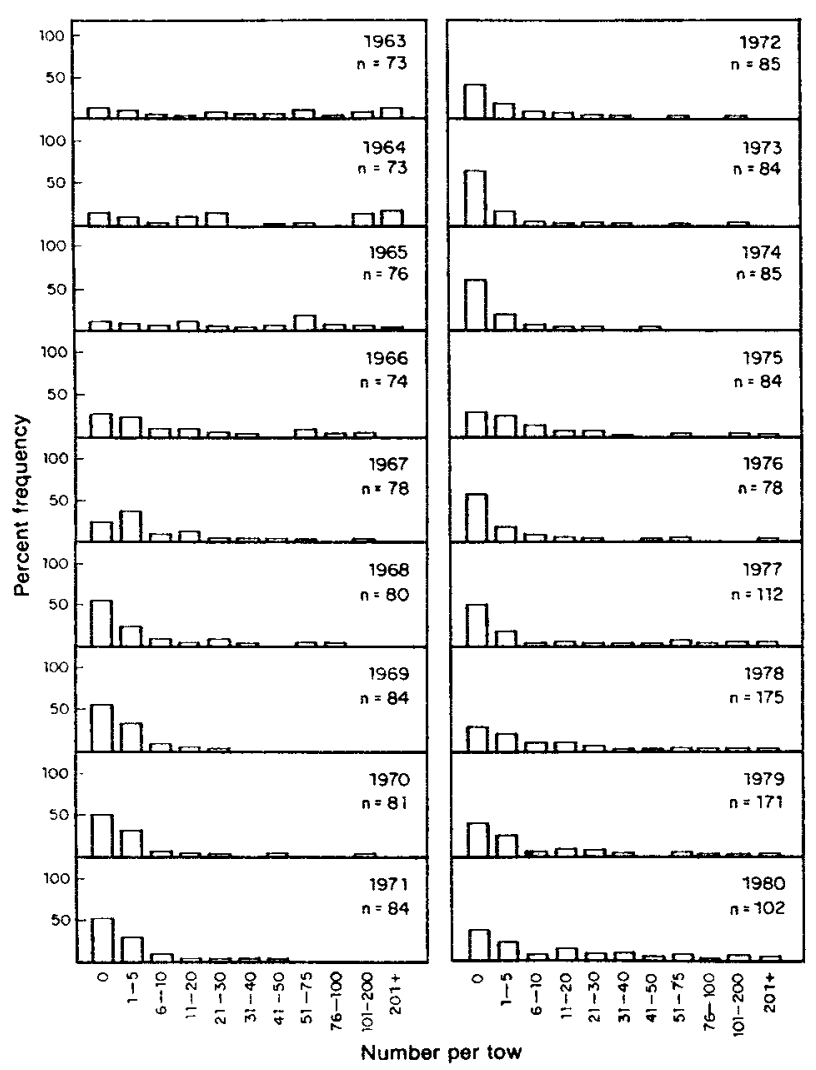

Fig. 6. Frequency distributions of catch per tow (numbers) for Georges Bank haddock, expressed as relative percentages of total numbers of tows, in USA autumn bottom-trawl surveys, 1963-80.

Also, variability in numbers caught per tow, measured by the coefficient of variation, increased from 0.17 for 1963-66 to 0.29 for $1967-75$ and subsequently remained high at 0.36 for $1976-80$. Trends were similar for catch per tow in weight, the corresponding values being $0.17,0.30$ and 0.33 respectively. Spatial patterns of abundance in the mid-1960's (not shown) indicated a tendency for haddock to be rather widely distributed over most of Georges Bank, whereas in recent years haddock tended to be concentrated along the northern edge and on the northeast peak of the bank (Fig. 2). These observations may indicate that the population distributes itself in different density patterns with changes in overall magnitude, resulting in changes in the underlying statistical distribution describing haddock observations in the survey data. This could well affect fishing success and the precision of survey estimates. Pennington and Grosslein (MS 1978) noted that the negative binomial distribution is most often appropriate for describing survey data, implying the use of a logarithmic transformation as a variancestabilizing approach, but the resulting distribution may not be normal. For Georges Bank, trends for indices calculated from transformed data, (i.e. In $(x+1)$, agreed very closely with trends for indices calculated from linear data, although agreement with numbers and biomass estimates calculated from virtual population analysis (VPA) was not as good for transformed values $(r=0.97$ and 0.89 in terms of numbers and $r=0.98$ and 0.94 in terms of weight for linear and transformed values respectively).

\section{Mortality}

Spring and autumn survey data (Tables 4 and 5) were used to examine trends in instantaneous total mortality ( $Z$ ). Estimates of $Z$ were obtained by catchcurve analyses of data for the more successful yearclasses, using fully-recruited portions of the curves (Fig. 7). Due to conspicuous differences in exploitation patterns during the 1960's, as reflected in curvilinearity of the plotted catch-per-tow values for several yearclasses, analyses were performed separately for 1964-67 data and data for later years. Analyses for Georges Bank were based on autumn survey data for 1963-80 and spring survey data for 1968-72, as gear configuration was the same for these periods. However, apparent seasonal differences in catchability precluded the use of spring survey data for the Gulf of Maine.

Mortality on the 1958-61 year-classes was quite high during 1964-67, $Z$ exceeding 0.8 in all cases, and was even higher on the 1962-64 year-classes, being $1.21,0.99$ and 1.16 respectively (Fig. 7). With instantaneous natural mortality $(M)$ of 0.2 , these high $Z$ values imply that instantaneous fishing mortality $(F)$ exceeded levels providing maximum yield per recruit or $F_{\max }$ (discussed below). As noted above, the exceptionally large 1962 and 1963 year-classes attracted heavy fishing pressure by USSR vessels during the mid-1960's, and mortality on the relatively small 1964 year-class was also high, as that year-class was vulnerable to capture during this period by trawls with $40-\mathrm{mm}$ mesh codend liners. With declining effort after 1967 , the average value of $Z$ for the 1961-64 year-classes declined from 1.05 during 1964-67 to 0.52 after 1967. However, mortality on more recent year-classes (1966, 1972 and 1975) was higher (Fig. 7).

Results for the Gulf of Maine differ somewhat from those obtained for Georges Bank (Fig. 7), although in general they appear to reflect observed distributions of fishing effort. Mortality on the 1958 year-class during 1964-67 was higher than on Georges Bank, estimates of $Z$ for the 1959 year-class were similar, and those for subsequent year-classes were generally lower, as would be expected in view of the concentration of fishing effort by distant-water fleets on Georges Bank during the mid-1960's.

Estimates of $\mathrm{Z}$ were also calculated by pooling survey data for age 3 and older fish over three periods 


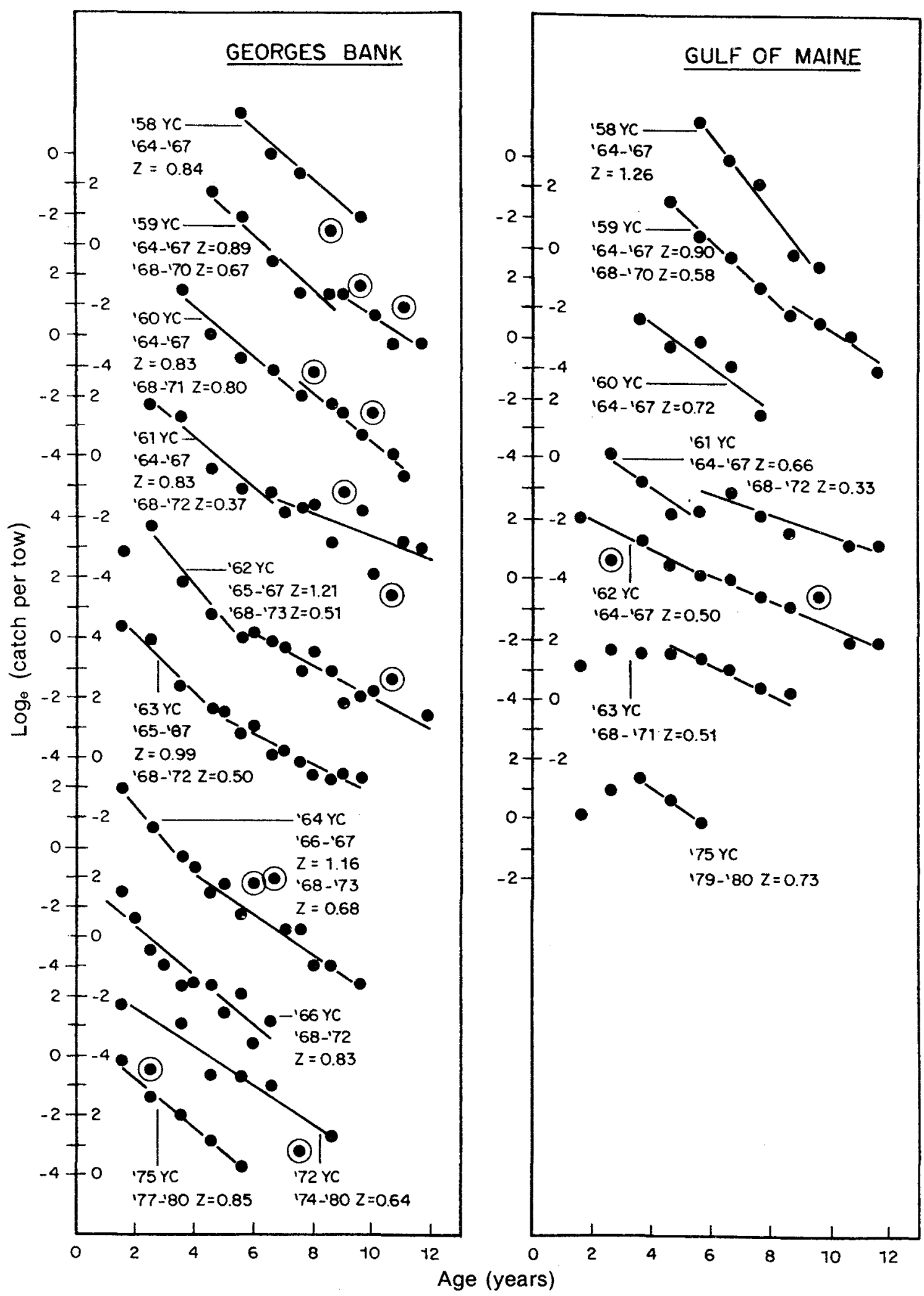

Fig. 7. Catch curves from selected year-classes of haddock in Georges Bank and Gulf of Maine areas, derived from analysis of USA spring and autumn bottom-trawl survey data. (Circled points not used in calculations.) 
(1964-67, 1968-72 and 1973-80), e.g. the 1964-67 autumn value was derived from

$$
\ln \left[\frac{\Sigma(\text { age } 3 \text { and older for } 1963-66)}{\Sigma(\text { age } 4 \text { and older for } 1964-67)}\right]
$$

and the 1968-72 spring value was derived from

$$
\ln \left[\frac{\Sigma(\text { age } 3 \text { and older for } 1968-71)}{\Sigma \text { (age } 4 \text { and older for } 1969-72)}\right]
$$

Results for Georges Bank indicate a decline in $\mathrm{Z}$ from 1.06 in 1964-67, when fishing effort by distant-water fleets was high, to an average of 0.50 in $1968-72$, as fishing effort declined due to reduced abundance. This was followed by an increase to an average of 0.67 in 1973-80 despite increasingly restrictive conservation measures (Table 6). For the Gulf of Maine, mortality in 1964-67 and 1973-80 was considerably lower than for Georges Bank, but results for 1968-72 were inconsistent $(Z=0.71$ and 0.44 from spring and autumn surveys respectively).

The above trends in mortality are in general agreement with the observed distribution of fishing effort by area and time. However, the estimates given in Table 6 should be considered with caution. Considerable variability is evident in the data used to derive these esti-

TABLE 6. Estimates of instantaneous total mortality (Z) based on spring and autumn bottom-trawl survey data for Georges Bank and the Gulf of Maine.

\begin{tabular}{lccccc}
\hline & \multicolumn{2}{c}{ Georges Bank } & & \multicolumn{2}{c}{ Gulf of Maine } \\
\cline { 2 - 3 } \cline { 5 - 6 } Period & Spring & Autumn & & Spring & Autumn \\
\hline $1963-67$ & - & 1.06 & - & 0.65 \\
$1968-72$ & 0.51 & 0.49 & 0.71 & 0.44 \\
$1973-80$ & 0.61 & 0.72 & 0.41 & 0.33 \\
\hline
\end{tabular}

mates, as would be expected from sampling different age-groups in a contagiously distributed population, and resulting impacts would be expected to be greatest during periods of low abundance. Also, average estimates of this type are usually most reliable when fishing mortality is relatively constant in each period of averaging, but it is unlikely that this condition was met during the periods considered with the possible exception of 1968-72.

\section{Growth}

Growth rates for Georges Bank haddock have fluctuated considerably, particularly since 1960 . During 1935-60, nominal catches, stock sizes and recruitment (discussed below) remained at relatively constant leveis, and the average weights of age 3 and older haddock in USA commercial landings exhibited no clear trend (Fig. 8). With declining recruitment and stock abundance in subsequent years, however, average weights increased substantially to peak levels in the 1970's.

The variability evident in mean weight-at-age data for USA commercial landings (Table 7) appears to reflect the effect of recruitment of several strong yearclasses. In particular, the outstanding 1963 year-class initially grew more slowly than others since the mid1930's and, together with the strong 1962 year-class, appears to have exerted a depressing effect on the growth of succeeding year-classes (i.e. those of 1964 and 1965). Similar trends are evident throughout the time series for other strong year-classes (Fig. 9); in fact, there was a decline in mean weight for all agegroups following every period of very strong recruitment (one or more year-classes of over 100 million fish at age 2). Recruitment of the very strong 1939 and 1940 year-classes was associated with declining mean weights at age in the mid-1940's, and the appearance of the very strong 1948, 1950 and 1952 year-classes was associated with a similar response in the 1950's. In the early to mid-1960's, the stock size increased to peak levels due to recruitment of the very strong 1958, 1959 and 1962 year-classes and the outstanding 1963 yearclass, and mean weights again declined (Fig. 9). The rapid increase in growth in the 1970's was associated

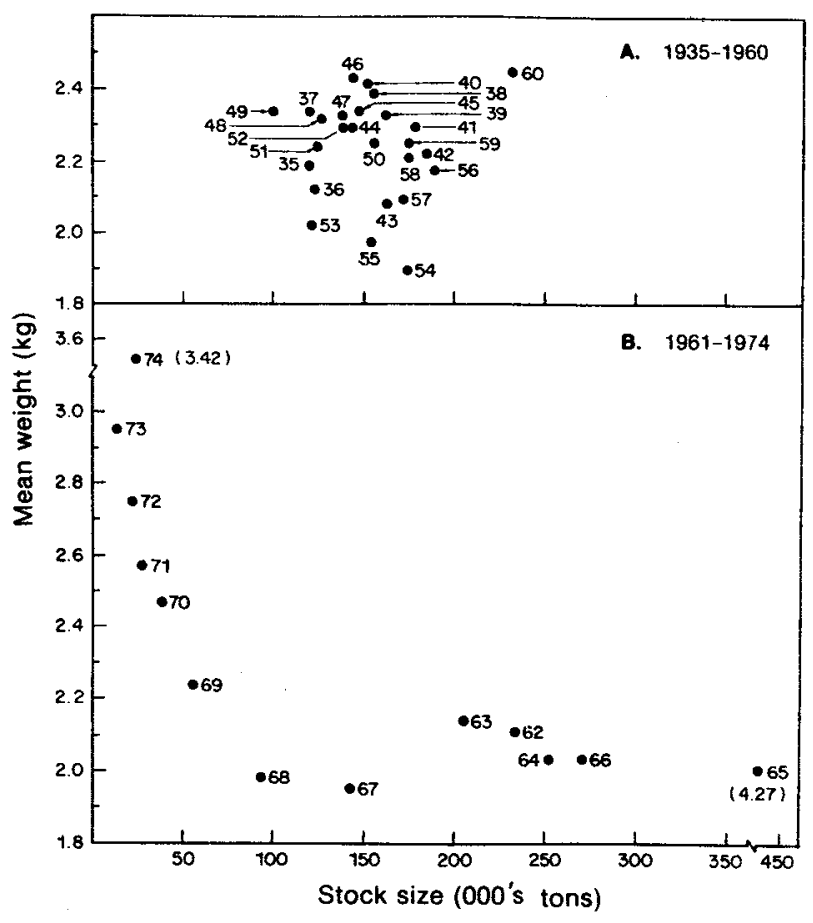

Fig. 8. Relation between mean weight of haddock (age 3 and older) in USA commercial landings from Georges Bank and stock size (age 2 and older) from virtual population analysis for (A) 1935-60 and (B) 1961-74 
TABLE 7. Mean weights ( $\mathrm{kg}$, whole) of haddock by age-group, as observed from samples of USA commercial landings from Georges Bank, 1931-79.

\begin{tabular}{|c|c|c|c|c|c|c|c|c|c|}
\hline \multirow[b]{2}{*}{ Year } & \multicolumn{9}{|c|}{ Mean weight at age $(\mathrm{kg})$} \\
\hline & 1 & 2 & 3 & 4 & 5 & 6 & 7 & 8 & $9+$ \\
\hline 1931 & 0.75 & 0.78 & 1.18 & 1.37 & 1.65 & 2.01 & 2.31 & 2.54 & 3.03 \\
\hline 1932 & 0.64 & 0.85 & 1.09 & 1.82 & 1.89 & 2.19 & 2.74 & 2.93 & 3.20 \\
\hline 1933 & 0.54 & 0.73 & 1.35 & 1.42 & 1.73 & 2.39 & 2.46 & 2.59 & 2.60 \\
\hline 1934 & 0.42 & 0.73 & 1.13 & 1.49 & 1.75 & 2.11 & 2.54 & 2.85 & 2.98 \\
\hline 1935 & 0.46 & 0.87 & 1.22 & 1.60 & 1.79 & 1.98 & 2.56 & 2.79 & 3.42 \\
\hline 1936 & 0.51 & 0.81 & 1.19 & 1.56 & 1.72 & 2.09 & 2.35 & 2.63 & 3.32 \\
\hline 1937 & 0.48 & 0.87 & 1.24 & 1.52 & 1.94 & 2.19 & 2.82 & 3.08 & 3.56 \\
\hline 1938 & 0.56 & 0.87 & 1.37 & 1.76 & 2.16 & 2.30 & 2.67 & 2.75 & 3.71 \\
\hline 1939 & 0.57 & 0.82 & 1.18 & 1.64 & 1.98 & 2.48 & 2.66 & 2.96 & 3.42 \\
\hline 1940 & 0.56 & 0.89 & 1.27 & 1.59 & 1.87 & 2.34 & 2.90 & 3.10 & 3.87 \\
\hline 1941 & 0.52 & 0.79 & 1.20 & 1.57 & 1.87 & 2.31 & 2.67 & 2.93 & 3.52 \\
\hline 1942 & 0.52 & 0.79 & 1.15 & 1.46 & 1.71 & 2.03 & 2.64 & 3.15 & 3.38 \\
\hline 1943 & 0.52 & 0.73 & 0.99 & 1.43 & 1.69 & 1.89 & 2.34 & 2.84 & 3.37 \\
\hline 1944 & 0.62 & 0.80 & 1.09 & 1.40 & 1.87 & 2.31 & 2.61 & 3.07 & 3.68 \\
\hline 1945 & 0.58 & 0.84 & 1.24 & 1.57 & 1.93 & 2.37 & 2.69 & 3.23 & 3.35 \\
\hline 1946 & 0.52 & 0.78 & 1.20 & 1.63 & 1.83 & 2.22 & 2.70 & 3.28 & 4.18 \\
\hline 1947 & 0.58 & 0.73 & 1.15 & 1.61 & 2.02 & 2.36 & 2.79 & 3.06 & 3.32 \\
\hline 1948 & 0.52 & 0.67 & 1.04 & 1.54 & 1.94 & 2.35 & 2.69 & 3.16 & 3.50 \\
\hline 1949 & 0.54 & 0.73 & 0.99 & 1.44 & 1.94 & 2.40 & 2.72 & 3.20 & 3.69 \\
\hline 1950 & 0.43 & 0.68 & 1.07 & 1.33 & 1.80 & 2.24 & 2.60 & 3.26 & 3.42 \\
\hline 1951 & 0.53 & 0.70 & 0.95 & 1.40 & 1.79 & 2.34 & 2.81 & 3.11 & 3.30 \\
\hline 1952 & - & 0.69 & 0.94 & 1.29 & 1.71 & 2.22 & 2.54 & 3.13 & 3.49 \\
\hline 1953 & 0.55 & 0.64 & 0.94 & 1.19 & 1.62 & 2.02 & 2.37 & 2.71 & 3.31 \\
\hline 1954 & 0.44 & 0.77 & 0.90 & 1.27 & 1.49 & 1.82 & 2.24 & 2.43 & 3.08 \\
\hline 1955 & 0.58 & 0.83 & 1.08 & 1.29 & 1.67 & 1.95 & 2.32 & 2.53 & 2.96 \\
\hline 1956 & 0.42 & 0.84 & 1.04 & 1.38 & 1.70 & 2.13 & 2.43 & 2.88 & 3.62 \\
\hline 1957 & 0.54 & 0.80 & 1.11 & 1.41 & 1.77 & 2.08 & 2.41 & 2.77 & 3.11 \\
\hline 1958 & 0.67 & 0.82 & 1.12 & 1.35 & 1.77 & 2.25 & 2.63 & 2.93 & 3.39 \\
\hline 1959 & 0.56 & 0.85 & 1.15 & 1.45 & 1.80 & 2.18 & 2.57 & 3.05 & 3.52 \\
\hline 1960 & 0.60 & 0.81 & 1.22 & 1.55 & 1.92 & 2.47 & 2.94 & 3.26 & 3.78 \\
\hline 1961 & 0.52 & 0.84 & 1.11 & 1.54 & 1.87 & 2.26 & 2.54 & 2.88 & 3.24 \\
\hline 1962 & 0.54 & 0.85 & 1.07 & 1.41 & 1.77 & 2.14 & 2.47 & 2.62 & 3.29 \\
\hline 1963 & 0.57 & 0.87 & 1.18 & 1.47 & 1.68 & 2.15 & 2.35 & 3.04 & 3.10 \\
\hline 1964 & 0.50 & 0.83 & 1.12 & 1.43 & 1.64 & 2.01 & 2.40 & 2.64 & 2.97 \\
\hline 1965 & 0.58 & 0.69 & 1.03 & 1.35 & 1.67 & 1.99 & 2.26 & 2.66 & 3.11 \\
\hline 1966 & 0.58 & 0.73 & 0.89 & 1.26 & 1.70 & 2.07 & 2.28 & 2.87 & 3.18 \\
\hline 1967 & 0.66 & 0.70 & 0.95 & 1.18 & 1.42 & 2.05 & 2.31 & 2.66 & 3.10 \\
\hline 1968 & 0.59 & 0.81 & 1.05 & 1.32 & 1.57 & 2.10 & 2.32 & 2.62 & 2.86 \\
\hline 1969 & 0.52 & 0.78 & 1.10 & 1.69 & 1.75 & 1.99 & 2.52 & 2.99 & 3.63 \\
\hline 1970 & 0.71 & 1.27 & 1.22 & 1.93 & 2.19 & 2.39 & 2.58 & 3.23 & 3.75 \\
\hline 1971 & - & 1.03 & 1.31 & 1.74 & 2.39 & 2.81 & 2.92 & 3.10 & 3.72 \\
\hline 1972 & 0.62 & 1.03 & 1.74 & 2.04 & 2.42 & 2.92 & 3.06 & 3.44 & 3.66 \\
\hline 1973 & 0.60 & 1.03 & 1.58 & 2.13 & 2.41 & 3.29 & 3.42 & 3.86 & 3.94 \\
\hline 1974 & 0.72 & 1.06 & 1.82 & 2.32 & 2.83 & 3.76 & 4.05 & 3.92 & 4.26 \\
\hline 1975 & 0.62 & 0.98 & 1.63 & 2.21 & 2.20 & 2.94 & 4.00 & 4.05 & 4.33 \\
\hline 1976 & 0.50 & 0.99 & 1.39 & 1.99 & 2.66 & - & 3.69 & 4.67 & 4.94 \\
\hline 1977 & - & 1.07 & 1.44 & 2.17 & 2.73 & 3.21 & 4.15 & 4.00 & 4.99 \\
\hline 1978 & - & 0.94 & 1.50 & 2.04 & 2.79 & 3.19 & 3.37 & 3.61 & 5.11 \\
\hline 1979 & - & 1.00 & 1.28 & 2.02 & 2.51 & 3.14 & 3.78 & 3.79 & 4.87 \\
\hline
\end{tabular}

with reductions in stock size in the late 1960's and early 1970's.

The rapid increase in growth of Georges Bank haddock evidenced in the late 1960's occurred in spite of generally declining temperatures (Davis, 1978), but temperature may have been a contributing factor in the early 1970's. The mean bottom temperature on Georges Bank increased from $4.4^{\circ} \mathrm{C}$ in 1971 to $6.3^{\circ} \mathrm{C}$ in 1974 (spring surveys) and from $10.5^{\circ} \mathrm{C}$ in 1970 to $12.7^{\circ} \mathrm{C}$ in 1973 (autumn surveys), although the latter values were not appreciably different from those in the mid-1960's (averaging $11.9^{\circ} \mathrm{C}$ ) when growth rates were substantially lower. However, stock biomass declined by more than $95 \%$ during $1965-72$. One obvious inference is that increased availability of food associated with declining recruitment and stock size in the late 1960's and early 1970's was responsible for the pronounced acceleration in growth during 1968-75.

Changes in haddock growth have been observed by several European researchers, notably Anderson (1938), Raitt (1939), Sonina $(1965,1969)$, Jones and Hislop (1978), and Jones (MS 1979). An apparent 


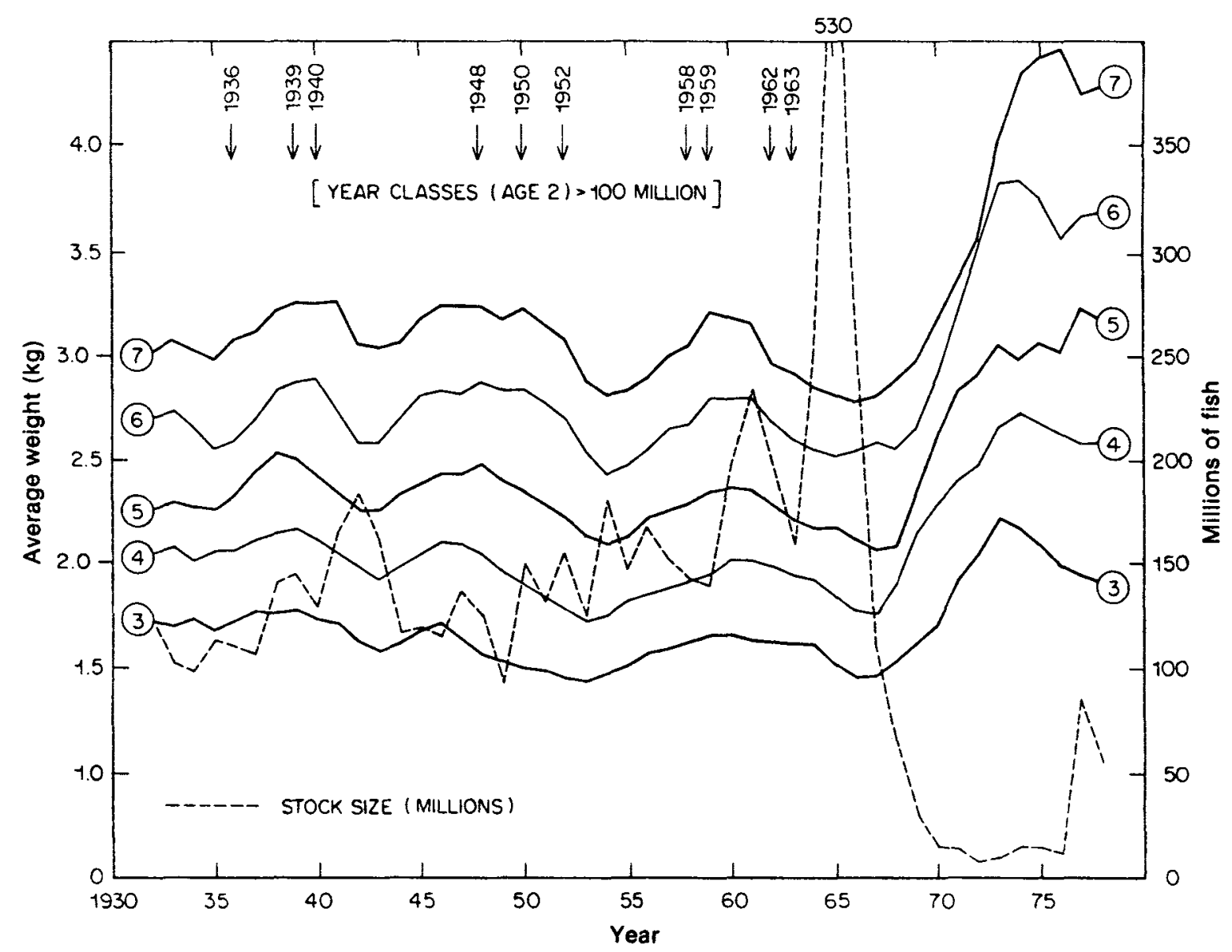

Fig. 9. Trends in mean weight at age and stock size (millions) for Georges Bank haddock, 1931-77.

inverse relationship between population abundance and growth was observed in all of these studies. Similarly, Templeman et al. (1978) and Templeman and Bishop (1979) observed inverse relationships between population abundance and growth for Grand Bank and St. Pierre Bank haddock (changes in abundance were determined to have been the major source of variation in growth for the Grand Bank population, but temperature may have contributed to the observed trends for the St. Pierre Bank population). For Grand Bank haddock, abundant year-classes appeared to have depressed growth of subsequent year-classes, as observed in the present study for Georges Bank haddock.

Commercial weight-at-age data for 1973-77 (Table 7) and length-at-age data from spring and autumn research vessel surveys during the same period do not reveal any consistent shifts in growth patterns and appear to be representative of recent conditions. Accordingly, survey data for 1973-77 were used to derive growth parameter estimates. Ages were determined from scales of 2,910 haddock from Georges Bank. By convention, 1 January was assumed to be the birthdate, and ages were coded such that a haddock hatched in a given year was assumed to be 0.3 years old during the spring survey (April) and 0.8 years old during the following autumn survey (October). The method of Tomlinson for unequal sample sizes (Abramson, 1971) was used to fit the von Bertalanffy growth equation.

$$
L_{t}=L_{\infty}\left(1-e^{-k\left(t-t_{0}\right)}\right)
$$

where $L t$ is fork length $(\mathrm{cm})$ at age $t, L$ is the maximum calculated length, $k$ is the Brody growth coefficient, and to is the hypothetical age at zero length. The resulting equation for Georges Bank haddock was

$$
L_{t}=73.80\left(1-e^{-0.3763(t-0.1649)}\right)
$$

A similar analysis of 1,249 specimens from the Gulf of Maine population provided the equation

$$
L_{t}=72.91\left(1-e^{-0.3524(t-0.2948)}\right)
$$

Predicted lengths at age indicate slightly slower growth for Gulf of Maine haddock (Fig. 10). 


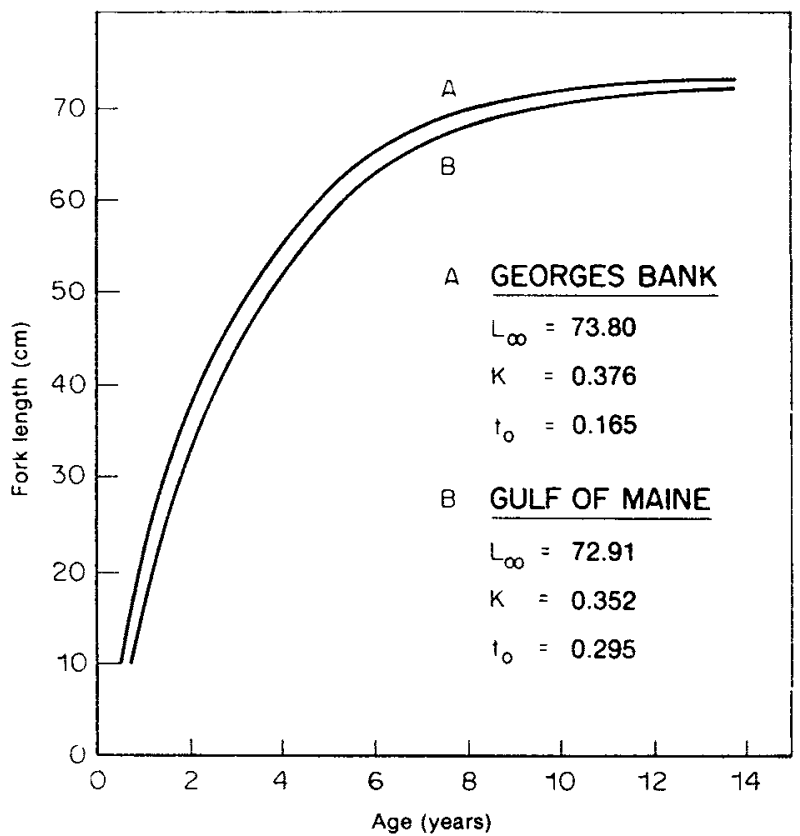

Fig. 10. Von Bertalanffy growth curves for Georges Bank and Gulf of Maine haddock, obtained from analysis of USA spring and autumn bottom-trawl survey data for 1973-77.

The calculated $L_{\infty}$ value of $73.8 \mathrm{~cm}$ for Georges Bank haddock is similar to that reported by Beverton (1965) for this stock $(73 \mathrm{~cm})$ although the $k$ value obtained in the present study is considerably higher $(0.376$ versus 0.28$)$. The latter value was derived from analysis of commercial length-at-age data, implying a downward bias in $\mathrm{k}$ due to commercial gear selectivity (resulting in omission of data for the younger agegroups).

\section{Yleld per Recruit}

Canadian and USA vessels, engaged in demersal trawling for haddock, cod and yellowtail flounder, Limanda ferruginea, in the Georges Bank-Gulf of Maine area, use gear fabricated of synthetic twine (usually polyamide fibres); current regulations for USA vessels require a stretched mesh size of at least $130 \mathrm{~mm}$ in the codend. Previous selectivity experiments with double braided polyamide trawls (Holden, 1971) indicated a selection factor of 3.4 for haddock. A similar value (3.5) was obtained by Smolowitz (MS 1978) during gear selectivity studies in the western Gulf of Maine. Use of data reported by Holden (1971) implies a mean selection length $\left(I_{c}\right)$ of $44.2 \mathrm{~cm}$, and application of the above growth equations implies a mean selection age $\left(t_{c}\right)$ of 2.6 years for Georges Bank haddock and 2.9 years for haddock in the Gulf of Maine. However, alleged use of smaller-meshed codends in the USA fishery in recent years implies that $t_{c}$ may actually be somewhat lower.

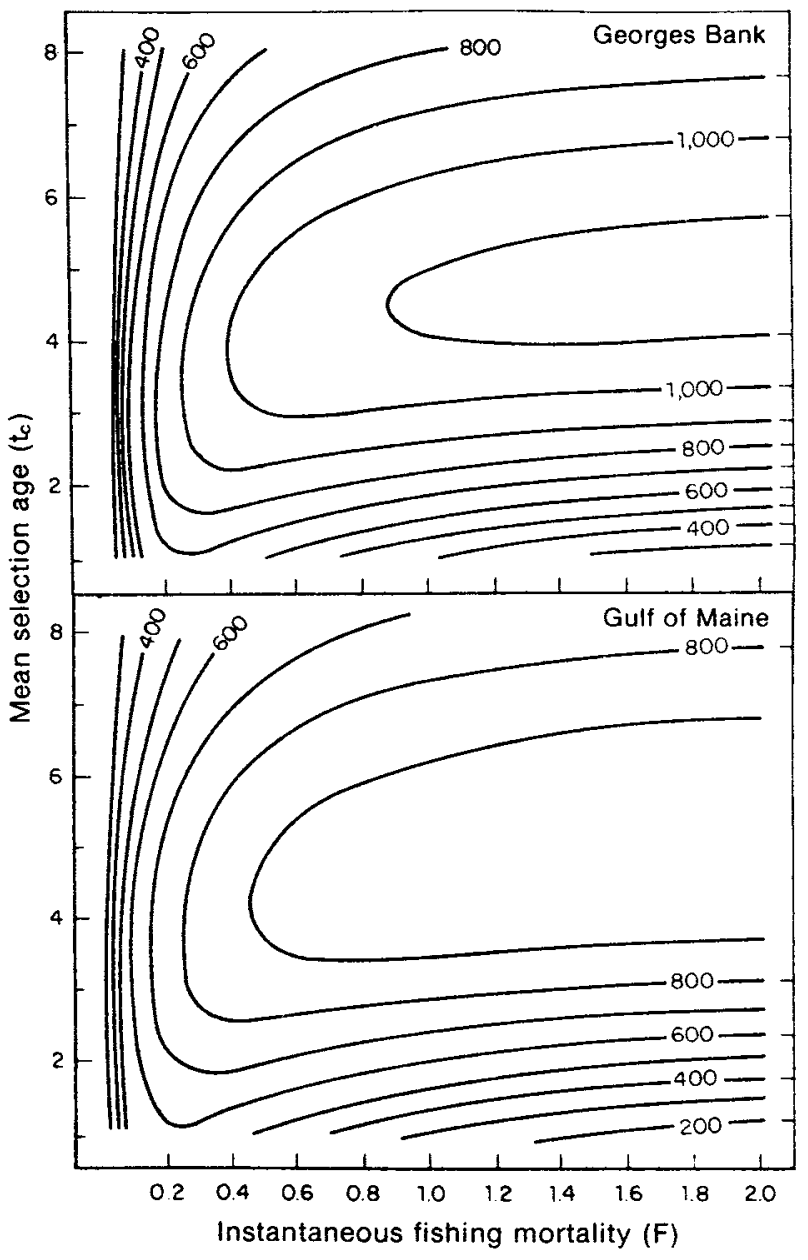

Fig. 11. Yield isopleths $(g)$ for Georges Bank and Gulf of Maine haddock, based on parameter estimates given in Table 8 .

TABLE 8. Parameters used in yield-per-recruit modeling for Georges Bank and Gulf of Maine haddock.

\begin{tabular}{lrr}
\hline \multicolumn{1}{c}{ Parameter } & $\begin{array}{c}\text { Georges } \\
\text { Bank }\end{array}$ & $\begin{array}{c}\text { Gulf of } \\
\text { Maine }\end{array}$ \\
\hline Fishing mortality, $F$ & $0.1-2.0$ & $0.1-2.0$ \\
Natural mortality, $M$ & 0.2 & 0.2 \\
Asymptotic weight, $W_{\infty}(\mathrm{gm})$ & 4,374 & 4.214 \\
Length-weight exponent, $\mathrm{b}$ & $3.07^{\mathrm{a}}$ & $3.07^{\mathrm{a}}$ \\
Brody growth coefficient, $\mathrm{K}$ & 0.3763 & 0.3524 \\
Hypothetical age at zero length, $\mathrm{t}_{0}(\mathrm{yr})$ & 0.1649 & 0.2946 \\
Age at recruitment, $\mathrm{t}_{\mathrm{r}}(\mathrm{yr})$ & 1.0 & 1.0 \\
Mean selection age, $\mathrm{t}_{\mathrm{c}}(\mathrm{yr})$ & $1.0-8.0$ & $1.0-8.0$ \\
Hypothetical maximum age, $\mathrm{t}_{\lambda}(\mathrm{yr})$ & 18 & 18 \\
\hline
\end{tabular}

${ }^{a}$ M. D. Grosslein, Northeast Fisheries Center, Woods Hole, per. comm., 1980)

Yield isopleths were calculated for the Georges Bank and Gulf of Maine stocks (Fig. 11) using the Paulik and Gales (1964) modification of the Beverton and Holt (1957) model and the parameters listed in Table 8. Transverse isopleths for Georges Bank for $t_{c}$ values of $2.0,2.5$ and 3.0 years indicate that yield per 
recruit is maximized at $F\left(F_{\max }\right)$ values of $0.36,0.47$ and 0.63 respectively, the corresponding $F_{0.1}$ values (Gulland and Boerema, 1973) being $0.21,0.23$ and 0.26 (Table 9). For the Gulf of Maine, $F_{\max }$ values of 0.32 , 0.41 and 0.54 and $F_{0.1}$ values of $0.19,0.22$ and 0.25 were

TABLE 9. $F_{\max }$ and $F_{0}$, values obtained for Georges Bank and Gulf of Maine haddock for three mean selection ages.

\begin{tabular}{cccccc}
\hline \multirow{2}{*}{$\begin{array}{c}\text { Selection } \\
\text { age }\end{array}$} & \multicolumn{2}{c}{ Georges Bank } & & \multicolumn{2}{c}{ Gulf of Maine } \\
\cline { 2 - 3 } \cline { 5 - 6 } & $F_{\max }$ & $F_{0.1}$ & & $F_{\max }$ & $F_{01}$ \\
\hline 2.0 & 0.36 & 0.21 & & 0.32 & 0.19 \\
2.5 & 0.47 & 0.23 & 0.41 & 0.22 \\
3.0 & 0.63 & 0.26 & & 0.54 & 0.25 \\
\hline
\end{tabular}

obtained for the same $t_{c}$ values. Calculations employing the unmodified Beverton and Holt yield model with the above growth parameter estimates for Georges Bank at the same $t_{c}$ values gave $F_{\max }$ values of $0.42,0.55$ and 0.76 and $F_{0.1}$ values of $0.22,0.26$ and 0.33 respectively (Clark and Overholtz, MS 1979).

\section{Stock Abundance and Recruitment}

\section{Georges Bank}

A VPA of the catch-at-age data for Georges Bank haddock (Table 2) was performed to estimate fishing mortality (F) and stock size for 1931-77. As haddock recruit strongly to the fishery at age 2 (partial recruitment has averaged about $75 \%$ for most recent yearclasses), total stock size estimates were calculated in terms of age 2 and older fish, and spawning stock size estimates were calculated as $50 \%$ of age 2 fish and $100 \%$ of age 3 and older fish. Natural mortality (M) was assumed to be 0.2 for all age groups, the value used in previous assessments of the Georges Bank stock.

The lack of directed fishing effort data for recent years (1974-77) due to incidental catch regulations precluded estimation of $F$ for 1977 from relationships between $F$ and fishing effort in preceding years. Accordingly, a special procedure was used to estimate a starting F-value for 1977 . Stock size estimates (numbers, age 3 and older) from a preliminary VPA with a trial F-value of 0.30 for 1977 were regressed against numbers per tow (age 2 and older, lagged one year) from autumn research vessel surveys for the 1964-74 period (Fig. 12). Stock size for 1977 was then predicted and used with known catch-at-age in numbers for 1977 to estimate exploitation rate $(u)$ and $F$ for 1977. This value of $F$ was then used as the starting $F$ in another VPA to generate new stock size estimates, and the procedure was repeated until $F$ for 1977 stabilized at 0.365 , the starting value used in the final VPA.

There is some doubt relative to the actual catch of age 3 and older haddock in 1977 (Table 2), as inciden-

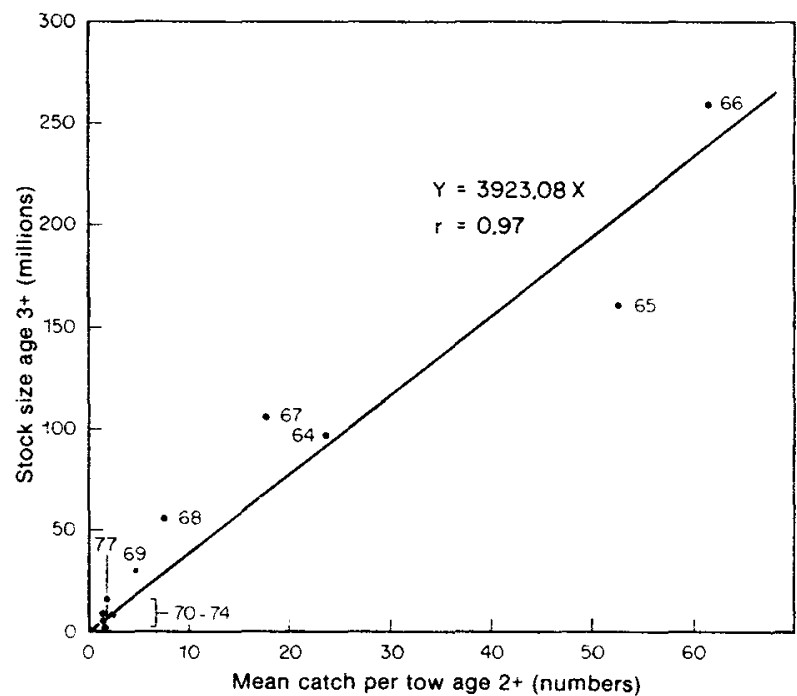

Fig. 12. Relation between stock size (age 3 and older) of Georges Bank haddock from virtual population analysis and mean catch per tow (age 2 and older) from USA autumn bottomtrawl surveys, 1964-74.

tal catch regulations were in effect during the summer and autumn of that year when the strong 1975 yearclass was recruiting to the fishery. Under these regulations, fishermen were allowed to retain and land only a small portion of the total haddock catch, which according to industry sources resulted in the discarding of large quantities (precise estimates being unavailable). This situation appears to have been unprecedented for the Georges Bank stock and was different from that under ICNAF management when TACs and/or incidental catch limitations were in effect but were not severely limiting due to low abundance. In the absence of length or age composition data for these discards, it could be assumed that significant quantities of age 3 and older haddock were discarded, but ancillary information indicates that discarding was confined primarily to age 2 fish (the recruiting 1975 year-class). In the few cases where information on discarding was reported, small (age 2) haddock were primarily involved; also, it is logical to assume that, in situations where both small and large haddock were available, fishermen would discard the smaller, lower-priced fish. Accordingly, it is believed that any downward bias in the 1977 estimate of $F$ (from lack of discard data for age 3 and older haddock) is not substantial. However, discarding of haddock and misreporting of haddock as other species occurred to a significant degree in 1978, and, because the 1975 year-class at age 3 was clearly involved, VPA was not applied to data for 1978-79. Results of this analysis are given in Tables 10 and 11 and Fig. 13.

Weighted estimates of $F$ (age $3^{+}$) declined from 0.62 in 1931 to 0.34 in 1934 (Table 10) as fishing effort declined following heavy exploitation in the late 1920's. Estimates subsequently averaged 0.44 during 1935-60, slightly lower than $F_{\max }$ which was about 0.5 for this 
TABLE 10. Instantaneous fishing mortality $(F)$, from virtual population analysis, with $M=0.20$, for Georges Bank haddock, $1931-77$.

\begin{tabular}{|c|c|c|c|c|c|c|c|c|c|c|}
\hline \multirow[b]{2}{*}{ Year } & \multicolumn{9}{|c|}{ Fishing mortality by age-group } & \multirow{2}{*}{$\begin{array}{c}\text { Mean } F^{a} \\
\text { Age 3+ }\end{array}$} \\
\hline & 1 & 2 & 3 & 4 & 5 & 6 & 7 & 8 & $9+$ & \\
\hline 1931 & 0.048 & 0.128 & 0.172 & 0.425 & 0.836 & 0.956 & 1.060 & 0.618 & 0.618 & 0.618 \\
\hline 1932 & 0.003 & 0.074 & 0.664 & 0.316 & 0.528 & 0.710 & 0.561 & 0.609 & 0.609 & 0.609 \\
\hline 1933 & 0.005 & 0.287 & 0.315 & 0.593 & 0.497 & 0.455 & 0.751 & 0.470 & 0.470 & 0.470 \\
\hline 1934 & 0.006 & 0.123 & 0.300 & 0.330 & 0.372 & 0.502 & 0.323 & 0.335 & 0.335 & 0.335 \\
\hline 1935 & 0.023 & 0.308 & 0.377 & 0.346 & 0.470 & 0.560 & 0.475 & 0.404 & 0.404 & 0.404 \\
\hline 1936 & 0.017 & 0.338 & 0.551 & 0.422 & 0.345 & 0.420 & 0.707 & 0.487 & 0.487 & 0.487 \\
\hline 1937 & 0.013 & 0.296 & 0.568 & 0.580 & 0.667 & 0.577 & 0.580 & 0.588 & 0.588 & 0.588 \\
\hline 1938 & 0.014 & 0.299 & 0.351 & 0.389 & 0.448 & 0.594 & 0.654 & 0.401 & 0.401 & 0.401 \\
\hline 1939 & 0.011 & 0.273 & 0.530 & 0.418 & 0.405 & 0.380 & 0.728 & 0.494 & 0.494 & 0.494 \\
\hline 1940 & 0.020 & 0.180 & 0.413 & 0.445 & 0.368 & 0.542 & 0.576 & 0.428 & 0.428 & 0.428 \\
\hline 1941 & 0.008 & 0.338 & 0.393 & 0.523 & 0.648 & 0.487 & 0.813 & 0.492 & 0.492 & 0.492 \\
\hline 1942 & 0.006 & 0.186 & 0.419 & 0.496 & 0.540 & 0.599 & 0.588 & 0.465 & 0.465 & 0.465 \\
\hline 1943 & 0.001 & 0.097 & 0.369 & 0.393 & 0.466 & 0.881 & 0.416 & 0.408 & 0.408 & 0.408 \\
\hline 1944 & 0.001 & 0.044 & 0.286 & 0.606 & 0.510 & 0.757 & 0.387 & 0.468 & 0.468 & 0.468 \\
\hline 1945 & 0.003 & 0.193 & 0.159 & 0.365 & 0.507 & 0.402 & 0.806 & 0.368 & 0.368 & 0.368 \\
\hline 1946 & 0.002 & 0.217 & 0.620 & 0.332 & 0.662 & $0.760^{\circ}$ & 0.644 & 0.602 & 0.602 & 0.602 \\
\hline 1947 & 0.002 & 0.274 & 0.525 & 0.683 & 0.467 & 0.782 & 0.783 & 0.599 & 0.599 & 0.599 \\
\hline 1948 & 0.003 & 0.284 & 0.585 & 0.540 & 0.612 & 0.503 & 0.534 & 0.574 & 0.574 & 0.574 \\
\hline 1949 & 0.003 & 0.302 & 0.586 & 0.662 & 0.514 & 0.510 & 0.562 & 0.601 & 0.601 & 0.601 \\
\hline 1950 & 0.002 & 0.370 & 0.319 & 0.407 & 0.505 & 0.503 & 0.508 & 0.404 & 0.404 & 0.404 \\
\hline 1951 & 0.007 & 0.208 & 0.687 & 0.279 & 0.433 & 0.725 & 0.734 & 0.617 & 0.617 & 0.617 \\
\hline 1952 & 0.000 & 0.386 & 0.361 & 0.491 & 0.282 & 0.295 & 0.392 & 0.397 & 0.397 & 0.397 \\
\hline 1953 & 0.009 & 0.057 & 0.514 & 0.419 & 0.420 & 0.350 & 0.276 & 0.466 & 0.466 & 0.466 \\
\hline 1954 & 0.002 & 0.389 & 0.227 & 0.305 & 0.297 & 0.449 & 0.452 & 0.291 & 0.291 & 0.291 \\
\hline 1955 & 0.001 & 0.106 & 0.432 & 0.226 & 0.294 & 0.358 & 0.426 & 0.372 & 0.372 & 0.372 \\
\hline 1956 & 0.001 & 0.190 & 0.264 & 0.533 & 0.382 & 0.559 & 0.559 & 0.419 & 0.419 & 0.419 \\
\hline 1957 & 0.001 & 0.157 & 0.355 & 0.286 & 0.535 & 0.499 & 0.582 & 0.389 & 0.389 & 0.389 \\
\hline 1958 & 0.002 & 0.128 & 0.252 & 0.284 & 0.412 & 0.434 & 0.362 & 0.305 & 0.305 & 0.305 \\
\hline 1959 & 0.001 & 0.139 & 0.272 & 0.294 & 0.271 & 0.342 & 0.399 & 0.288 & 0.288 & 0.288 \\
\hline 1960 & 0.002 & 0.184 & 0.216 & 0.246 & 0.285 & 0.190 & 0.253 & 0.233 & 0.233 & 0.233 \\
\hline 1961 & 0.001 & 0.124 & 0.261 & 0.225 & 0.246 & 0.279 & 0.199 & 0.250 & 0.250 & 0.250 \\
\hline 1962 & 0.002 & 0.117 & 0.280 & 0.294 & 0.292 & 0.279 & 0.402 & 0.290 & 0.290 & 0.290 \\
\hline 1963 & 0.017 & 0.151 & 0.291 & 0.316 & 0.397 & 0.308 & 0.307 & 0.327 & 0.327 & 0.327 \\
\hline 1964 & 0.024 & 0.124 & 0.253 & 0.308 & 0.438 & 0.543 & 0.535 & 0.387 & 0.387 & 0.387 \\
\hline 1965 & 0.392 & 0.468 & 0.593 & 0.531 & 0.517 & 0.718 & 0.846 & 0.605 & 0.605 & 0.605 \\
\hline 1966 & 0.032 & 0.540 & 0.870 & 0.555 & 0.584 & 0.666 & 0.594 & 0.791 & 0.791 & 0.791 \\
\hline 1967 & 0.113 & 0.060 & 0.462 & 0.430 & 0.670 & 0.550 & 0.587 & 0.495 & 0.495 & 0.495 \\
\hline 1968 & 0.024 & 0.477 & 0.377 & 0.644 & 0.616 & 0.503 & 0.694 & 0.588 & 0.588 & 0.588 \\
\hline 1969 & 0.002 & 0.042 & 0.549 & 0.436 & 0.473 & 0.557 & 0.445 & 0.524 & 0.524 & 0.524 \\
\hline 1970 & 0.012 & 0.247 & 0.080 & 0.358 & 0.325 & 0.278 & 0.436 & 0.393 & 0.393 & 0.393 \\
\hline 1971 & 0.000 & 0.559 & 0.652 & 0.292 & 0.311 & 0.955 & 0.727 & 0.552 & 0.552 & 0.552 \\
\hline 1972 & 0.020 & 0.040 & 0.357 & 0.526 & 0.401 & 0.205 & 0.964 & 0.363 & 0.363 & 0.363 \\
\hline 1973 & 0.221 & 0.386 & 0.077 & 0.594 & 0.799 & 0.823 & 0.196 & 0.484 & 0.484 & 0.484 \\
\hline 1974 & 0.008 & 0.242 & 0.204 & 0.067 & 0.199 & 0.059 & 0.111 & 0.201 & 0.201 & 0.201 \\
\hline 1975 & $0.122^{b}$ & 0.231 & 0.418 & 0.172 & 0.186 & 0.176 & $0.16 \mathrm{C}$ & 0.337 & 0.337 & 0.337 \\
\hline 1976 & $0.001^{b}$ & 0.490 & 0.185 & 0.356 & 0.142 & 0.006 & 0.138 & 0.237 & 0.237 & 0.237 \\
\hline 1977 & $\ldots^{c}$ & $\ldots^{c}$ & 0.365 & 0.365 & 0.365 & 0.365 & 0.365 & 0.365 & 0.365 & 0.365 \\
\hline
\end{tabular}

${ }^{a}$ Weighted by stock size in numbers over age-groups 3 to 7 ; used as starting $F$ for age-groups 8 and $9+$.

${ }^{\circ}$ Predicted value.

${ }^{c}$ Cannot be estimated due to high discarding and misreporting in 1977

period (Hennemuth, MS 1969). During the late 1950's and early 1960's, F declined somewhat and then steadily increased to 0.79 in 1966 as fishing effort by distantwater fleets intensified. Subsequently, $F$ declined to relatively low levels in the 1970's coincident with low recruitment and redirection of fishing effort to other species. These trends are generally consistent with those evidenced by analysis of research vessel survey data, although the decline in average $F$ from $1964-67$ to $1968-72$ based on survey data $(0.86$ to 0.30 , assuming
$M=0.2$, Table 6) was greater than that indicated by VPA for the same periods $(0.64$ to 0.53 , Table 10$)$.

Total stock size (age 2 and older) increased from 100 million fish $(113,000$ tons $)$ in $1933-34$ to an average of 140 million fish (153,000 tons) in 1935-60 (Table 11, Fig. 13). During the late 1950's and early 1960's, however, stock size increased more or less continuously, particularly in the latter part of this period due to significant contributions by the very strong 1958 and 1959 
TABLE 11. Stock sizes from virtual population analysis, with $M=0.2$, for Georges Bank haddock, 1931-78. (Weights calculated by applying mean weight-at-age data for first quarter of each year.)

\begin{tabular}{|c|c|c|c|c|c|c|c|c|c|c|c|c|c|}
\hline \multirow[b]{3}{*}{ Year } & \multirow{2}{*}{\multicolumn{9}{|c|}{ Stock size by age-group (000s) }} & \multicolumn{2}{|c|}{ Total stock (age $2+$ ) } & \multicolumn{2}{|c|}{ Spawning stock } \\
\hline & & & & & & & & & & \multirow{2}{*}{$\begin{array}{c}\text { Number } \\
\text { (000s) }\end{array}$} & \multirow{2}{*}{$\begin{array}{l}\text { Weight } \\
\text { (tons) }\end{array}$} & \multirow{2}{*}{$\begin{array}{c}\text { Number } \\
\text { (000s) }\end{array}$} & \multirow{2}{*}{$\begin{array}{c}\text { Weight } \\
\text { (tons) }\end{array}$} \\
\hline & 1 & 2 & 3 & 4 & 5 & 6 & 7 & 8 & $9+$ & & & & \\
\hline 1931 & 41,183 & 80.780 & 14,217 & 18.310 & 17.482 & 10.670 & 5,608 & 4,249 & 1,324 & 152,640 & 180.209 & 112,250 & 151.533 \\
\hline 1932 & 45,586 & 32,138 & 58,205 & 9,801 & 9,801 & 6,205 & 3,360 & 1,590 & 936 & 122,036 & 129,600 & 105,967 & 123,172 \\
\hline 1933 & 52,103 & 37.314 & 24,435 & 24,539 & 5,849 & 4,733 & 2,496 & 1,570 & 1,889 & 102,825 & 117,599 & 84,168 & 105,286 \\
\hline 1934 & 60.477 & 42.517 & 22,930 & 14,594 & 11,105 & 2,915 & 2,459 & 964 & 648 & 98,132 & 108,404 & 76.874 & 94,373 \\
\hline 1935 & 58,872 & 49,226 & 30.795 & 13,907 & 8,594 & 6,265 & 1,445 & 1.457 & 359 & 112,048 & 120,207 & 87,435 & 104,208 \\
\hline 1936 & 58,645 & 47,132 & 29,634 & 17.296 & 8.058 & 4,397 & 2.929 & 736 & 352 & 110,534 & 123,837 & 86,968 & 109,933 \\
\hline 1937 & 106,346 & 47,215 & 27,515 & 13,981 & 9,289 & 4,674 & 2,365 & 1,182 & 546 & 106,767 & 120,143 & 83,160 & 105,743 \\
\hline 1938 & 79,251 & 85,910 & 28,739 & 12,764 & 6,410 & 3,904 & 2,149 & 1,085 & 574 & 141,535 & 155,661 & 98,580 & 120,867 \\
\hline 1939 & 59.750 & 63,993 & 52,183 & 16.565 & 7,080 & 3,354 & 1,765 & 915 & 671 & 146,526 & 161.572 & 114,530 & 140,134 \\
\hline 1940 & 111,805 & 48,379 & 39,862 & 25,158 & 8,930 & 3,866 & 1,878 & 698 & 428 & 129,199 & 152,253 & 105,010 & 134,836 \\
\hline 1941 & 114,103 & 89,700 & 33,077 & 21,586 & 13,197 & 5.058 & 1,841 & 864 & 1,081 & 166.404 & 179.284 & 121,554 & 152.374 \\
\hline 1942 & 61,462 & 92,731 & 52,365 & 18,279 & 10.479 & 5,654 & 2,545 & 669 & 518 & 183,240 & 185,096 & 136,875 & 154,495 \\
\hline 1943 & 23,566 & 50,122 & 63,038 & 28,207 & 9,114 & 5,002 & 2,544 & 1,157 & 582 & 159.766 & 163,552 & 134,705 & 151,021 \\
\hline 1944 & 64,821 & 19.422 & 37,261 & 35,685 & 15,588 & 4,681 & 1,698 & 1,374 & 316 & 116,025 & 142,963 & 106,314 & 137,913 \\
\hline 1945 & 51,611 & 53,281 & 15,216 & 22,921 & 15,942 & 7,667 & 1,798 & 944 & 730 & 118,499 & 147,149 & 91,859 & 125,570 \\
\hline 1946 & 93,096 & 42,009 & 35,950 & 10,630 & 13,033 & 7.861 & 4.200 & 657 & 56 & 114,396 & 144,026 & 93,392 & 131,423 \\
\hline 1947 & 60,971 & 76,237 & 27,673 & 15,831 & 6,243 & 5,501 & 3,010 & 1,806 & 1,108 & 137,409 & 138,934 & 99,291 & 114,538 \\
\hline 1948 & 33,352 & 49,872 & 47,472 & 13,402 & 6,547 & 3,205 & 2.062 & 1,126 & 923 & 124,609 & 126,777 & 99.673 & $1+1,317$ \\
\hline 1949 & 125,835 & 27,266 & 30.739 & 21,657 & 6,393 & 2,907 & 1,588 & 989 & 854 & 92,393 & 99,760 & 78,760 & 91,581 \\
\hline 1950 & 58,894 & 102,756 & 16,506 & 14,003 & 9,146 & 3,132 & 1.429 & 741 & 824 & 148,537 & 156,023 & 97,159 & 111,838 \\
\hline 1951 & 105,619 & 48,368 & 58,120 & 9.824 & 7,632 & 4.519 & 1,551 & 704 & 510 & 131,228 & 124,762 & 107,044 & 108,077 \\
\hline 1952 & 43,589 & 85,981 & 32,160 & 23,941 & 6,086 & 4,053 & 1,791 & 609 & 358 & 154,979 & 139,367 & $\uparrow 11,989$ & 110.994 \\
\hline 1953 & 133,495 & 35,688 & 47,848 & 18,346 & 11,999 & 3.759 & 2,470 & 991 & 447 & 121,548 & 120,428 & 103,704 & 109,543 \\
\hline 1954 & 52,552 & 108,354 & 27,590 & 23,421 & 9,884 & 6,454 & 2,169 & 1,535 & 426 & 179,833 & 174,869 & 125,656 & 131,528 \\
\hline 1955 & 92,857 & 43,107 & 60,121 & 17.993 & 14,133 & 6,011 & 3,373 & 1.130 & 611 & 146,479 & 155,140 & 124,926 & 137.897 \\
\hline 1956 & 61.067 & 76,081 & 31.741 & 31,957 & 11,747 & 8,624 & 3,441 & 1,804 & 643 & 166,038 & 188,771 & 127,998 & 157,958 \\
\hline 1957 & 62,310 & 49,998 & 51,533 & 19,963 & 15,361 & 6,562 & 4,038 & 1,617 & 1,245 & 150,311 & 171,726 & 125,312 & 150,727 \\
\hline 1958 & 59,260 & 51,137 & 34,995 & 29,579 & 12,278 & 7,363 & 3,261 & 1,847 & 593 & 141,053 & 175,513 & 115,485 & 151,990 \\
\hline 1959 & 126,540 & 48,613 & 36,847 & 22,277 & 18,225 & 6,658 & 3,907 & 1,859 & 1,466 & 139,852 & 175,934 & 115,546 & 154,788 \\
\hline 1960 & 123,370 & 104,753 & 34,651 & 22,979 & 13,592 & 11,384 & 3,872 & 2,147 & 1,840 & 195,218 & 232,377 & 142.842 & 187.334 \\
\hline 1961 & 53.899 & 100,927 & 71,348 & 22,860 & 14,709 & 8,371 & 7,707 & 2,462 & 3,348 & 231,732 & 269,626 & 181,269 & 226,732 \\
\hline 1962 & 38,736 & 44,363 & 72,995 & 44,990 & 14,938 & 9,418 & 5,185 & 5,170 & 3,917 & 200,976 & 233,529 & 178,795 & 218,002 \\
\hline 1963 & 186.718 & 31,766 & 32,305 & 45.158 & 27.450 & 9,131 & 5,833 & 2,840 & 4,312 & 158,795 & 205,068 & 142,912 & 194,585 \\
\hline 1964 & 460,854 & 150,289 & 22,361 & 19,781 & 26,951 & 15,117 & 5.494 & 3,513 & 4,550 & 248,056 & 252,423 & 172,912 & 202,827 \\
\hline 1965 & 32,436 & 368,278 & 108,689 & 14,212 & 11,903 & 14,244 & 7,190 & 2,634 & 3.287 & 530,437 & 426,817 & 346,298 & 314,493 \\
\hline 1966 & 4,040 & 17,940 & 188,745 & 49,185 & 6,840 & 5,813 & 5,690 & 2,526 & 1,728 & 278,467 & 271,349 & 269.497 & 267,313 \\
\hline 1967 & 11,822 & 3,205 & 8,562 & 64,755 & 23,112 & 3,123 & 2,444 & 2,572 & 1.956 & 109.729 & 143,354 & 108.127 & 142,489 \\
\hline 1968 & 366 & 8.643 & 2.473 & 4,418 & 34,481 & 9,687 & 1,475 & 1.113 & 2,070 & 64,360 & 93,321 & 60,039 & 89,604 \\
\hline 1969 & 969 & 293 & 4,393 & 1,388 & 1,900 & 15,248 & 4,796 & 603 & 1,529 & 30,150 & 56.471 & 30.004 & 56,341 \\
\hline 1970 & 4,337 & 794 & 230 & 2,076 & 735 & 970 & 7.155 & 2,516 & 1,565 & 16,041 & 39,342 & 15,644 & 38,977 \\
\hline 1971 & $70^{\circ}$ & 3.511 & 508 & 174 & 1,188 & 435 & 601 & 3,788 & 2,392 & 12,597 & 28,016 & 10.842 & 26,629 \\
\hline 1972 & 8,763 & 57 & 1,644 & 217 & 106 & 713 & 137 & 238 & 4,453 & 7,565 & 21,850 & 7,537 & 21,827 \\
\hline 1973 & 14,172 & 7,035 & 45 & 942 & 105 & 58 & 476 & 43 & 1,275 & 9,979 & 14,432 & 6,462 & 11,548 \\
\hline 1974 & 6,783 & 9,300 & 3,914 & 34 & 426 & 39 & 21 & 320 & 1,504 & 15,558 & 21,693 & 10,908 & 18,159 \\
\hline 1975 & 1,844 & 5,513 & 5,977 & 2,613 & 26 & 285 & 30 & 15 & 338 & 14,797 & 22,588 & 12,041 & 20,245 \\
\hline 1976 & $94,000^{\circ}$ & 1,337 & 3,583 & 3,221 & 1,801 & 18 & 196 & 21 & 583 & 10,760 & 21,594 & 10,092 & 20,939 \\
\hline 1977 & $23,000^{\mathrm{b}}$ & $77,000^{c}$ & 671 & 2,439 & 1,847 & 1,280 & 14 & 140 & 398 & 83,789 & 72,524 & 45,289 & 44,804 \\
\hline 1978 & $4,000^{b}$ & $19,000^{c}$ & $32,000^{c}$ & $381^{\circ}$ & $1,386^{d}$ & $1,050^{d}$ & $728^{d}$ & $8^{0}$ & $306^{d}$ & 54,859 & 66,210 & 45,369 & 59,275 \\
\hline
\end{tabular}

year-classes. Stock size subsequently peaked at 530 million fish $(427,000$ tons) in 1965 due to recruitment of the very strong 1962 and the outstanding 1963 yearclasses, the latter being estimated to have consisted of 368 million fish at age 2, six times larger than the 1935-60 year-class average. Stock abundance declined precipitously in the late 1960's and early 1970 's to an average level of 9 million fish (18,000 tons) in 1972-73 in response to over-exploitation and poor recruitment, and, after averaging 14 million fish $(22,000$ tons) during 1974-76, rose sharply in 1977 with recruitment of the 1975 year-class.

Trends in estimates of spawning stock size have paralleled those observed for total stock size, decreasing to a low of 77 million fish (94,000 tons) in 1934 and then increasing to an average of 109 million fish (131,000 tons) during 1935-60 (Table 11). Spawning stock size subsequently peaked at 346 million fish (314,000 tons) in 1965 before declining to an apparent all-time low of 6 million fish (12,000 tons) in 1973. Since then, it increased to an average of 11 million fish (20,000 tons) during $1974-76$ and rose sharply in $1977-78$ as the 1975 year-class matured.

Estimation of stock abundance for 1977 and subsequent years is obviously dependent on estimates of recruiting year-class size. For 1977, the 1975 year- 


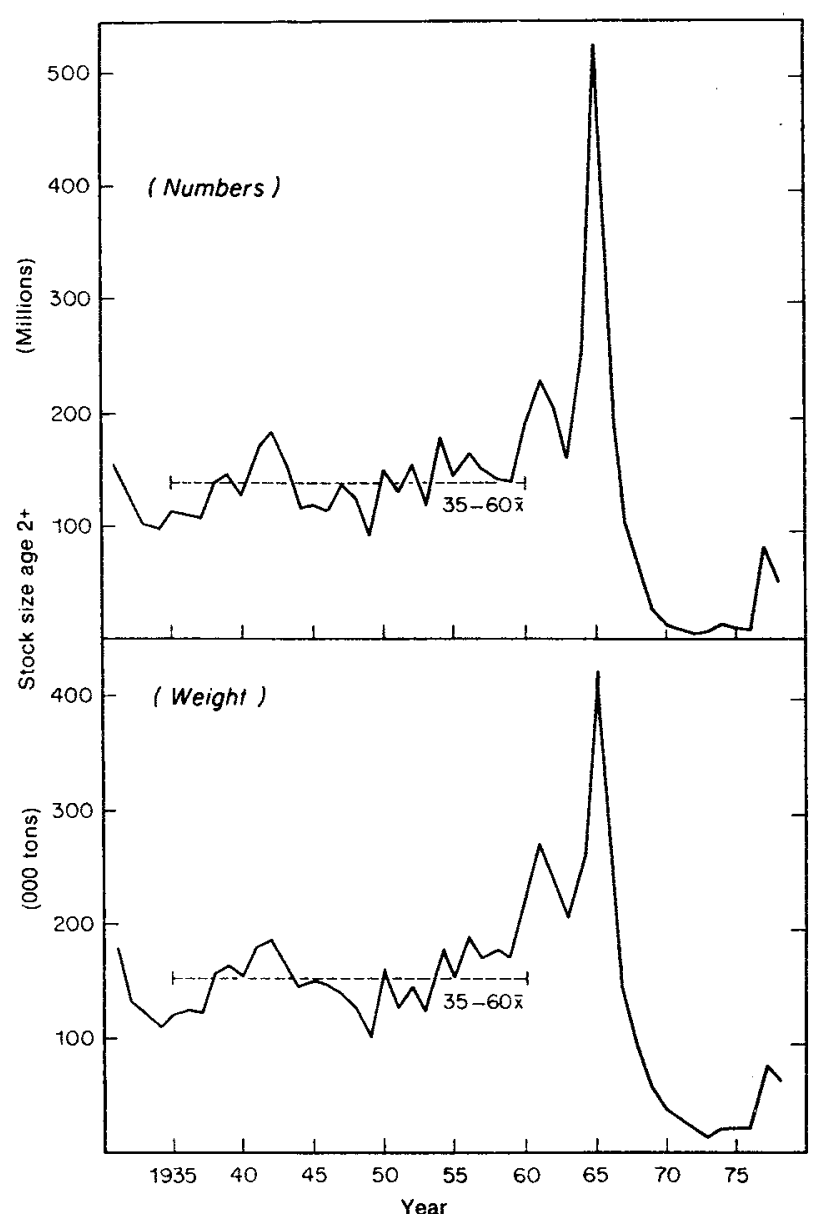

Fig. 13. Trends in stock size (number and weight) of age 2 and older haddock on Georges Bank, estimated from virtual population analysis, 1931-78.

class estimate is critical due to the apparent strength of this year-class and low abundance of older fish. This year-class dominated 1977-79 survey catches of age 2 and older fish on Georges Bank (Tables 4 and 5) and was also the strongest to appear in surveys conducted by Federal Republic of Germany and USSR research vessels in cooperation with USA during 1973-76, its size being estimated at more than 100 million fish at age 2 based on simple ratios of catch per tow of the 1972 and 1975 year-classes at age 1 (Clark and Overholtz, MS 1979).

Estimation of the sizes of the 1975 and subsequent year-classes has been complicated by uncertainty about nominal catch at age and variability in survey abundance indices. Variability in catch per tow has increased during the available time series (1968-80 for spring surveys and 1963-80 for autumn surveys) and was particularly high in 1976 and 1979 due primarily to anomalous catch-per-tow values for age $1 \mathrm{fish}$. Therefore, the potential exists for distortion of empirical relationships between VPA estimates of year-class size

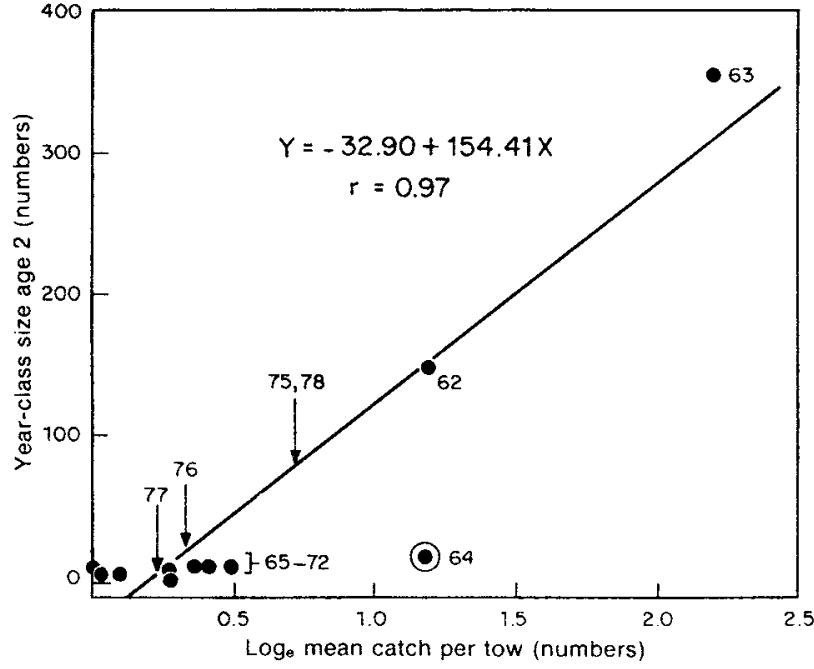

Fig. 14. Relation between year-class size of haddock (age 2) from virtual population analysis and mean catch per tow (based on In $x+1$ values) from USA autumn bottom-trawl surveys on Georges Bank, 1962-78.

and survey abundance indices. Also, the available time series is limited and includes points varying widely in magnitude, and thus predictive regressions for estimation of year-class size would be expected to be quite sensitive to deletion of existing data points and/or incorporation of additional ones. Consequently, estimates of year-class size predicted from such regressions should be treated with caution, although results from this study are consistent with survey data and industry reports indicating the 1975 and 1978 yearclasses to be strong ones. The 1975 and 1978 yearclasses appear to have been comparable in size, based on spring and autumn survey abundance indices (Tables 4 and 5), and estimates obtained from a linear regression of VPA numbers at age 2 on mean catch per tow of age 1 fish in autumn surveys, calculated from $\ln (\mathrm{x}+1)$ values (Fig. 14), were very similar ( 77 million fish, with a $95 \%$ confidence interval of \pm 21 million fish). Estimates of the sizes of the 1976 and 1977 yearclasses at age 2 were substantially lower $(19$ million and 3 million fish respectively). Similar relationships based on untransformed data provided estimates of 165 million and 138 million fish for the 1975 and 1978 year-classes (Clark and Overholtz, MS 1979; Clark and Essig, MS 1980). The above estimate of 77 million fish at age 2 for the 1975 year-class implies a total stock size of 84 million fish $(73,000$ tons) and a spawning stock size of 45 million fish (45,000 tons) in 1977 (Table 11).

The reliability of the above estimates is difficult to verify, but ancillary information does support the 1975 year-class size estimate of 77 million fish. A similar regression of VPA numbers at age 3 on mean catch per tow at age 2 in autumn surveys provided an estimate of 
32 million fish at age 3 (95\% confidence interval of ' 12 million fish). This value is obviously incompatible with nominal catch-at-age data for this year-class, but it does not appear unreasonable in view of information on discarding in 1977 and total mortality estimates from survey data. Interviews conducted in August 1977 indicated that quantities discarded may have exceeded the reported landings in weight by a factor of 4 , and if the smallest fish were discarded, the factor in terms of numbers was probably considerably larger. A total catch (including discards) of 36 million fish, implying a discard rate equal to 5 times the reported catch of the 1975 year-class in 1977 , would have generated $F[0.71$ or $Z$ [ 0.91, very similar to the average $Z(0.89)$ for 1977 based on spring and autumn survey data.

Pronounced differences are evident in the distribution of recruiting year-class size (age 2) between 1935-60, when stock size was relatively stable, and 1961-80, when stock abundance peaked and then declined precipitously (Fig. 15). During 1935-60, yearclass size was relatively constant, with almost half of the recruiting year-classes being in the order of 40-50 million fish. The frequency distribution of year-class size for this period is noticeably skewed (mean of 61 million fish, with a range of 19-108 million fish), but

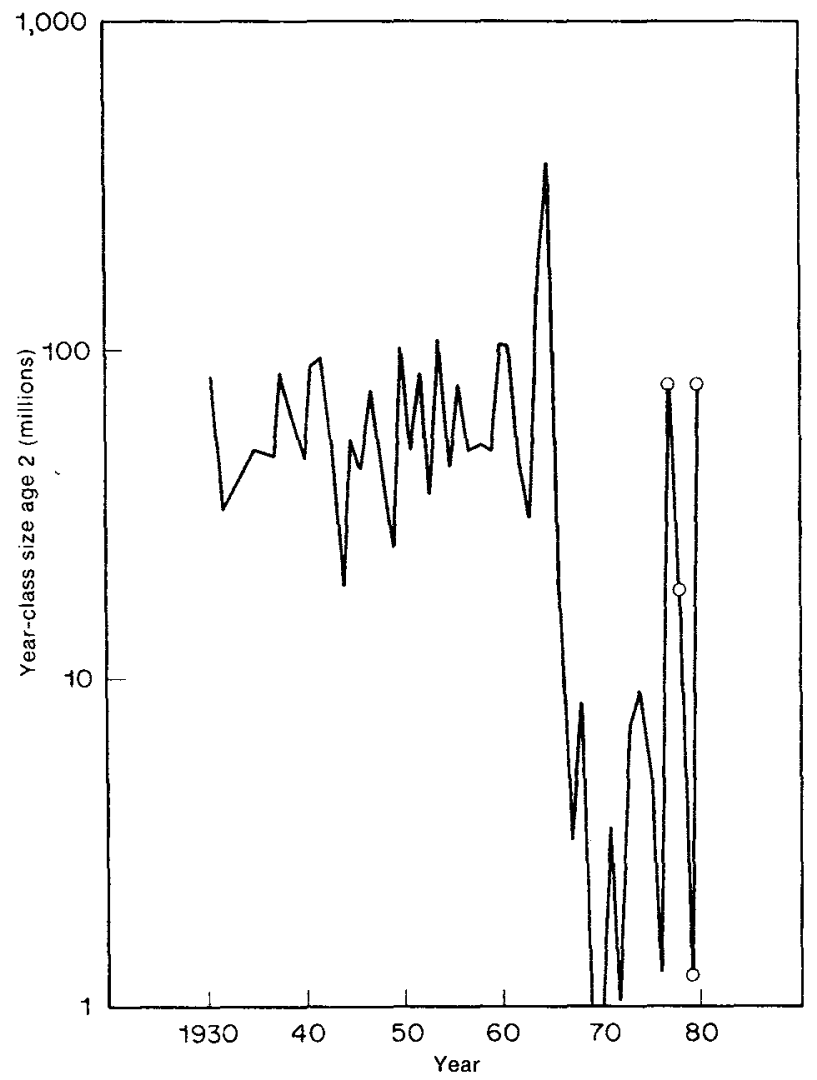

Fig. 15. Recruiting year-class size of haddock (age 2) on Georges Bank from virtual population analysis, 1931-80. (Estimates for last 4 year-classes are predicted.) variation was small compared to that for later years. "Strong" year-classes (75-100 million fish) occurred on an average of once every 3 years, and "very strong" year-classes ( $>100$ million fish) occurred occasionally. During the same period, spawning biomass was generally in the range of 100,000-160,000 tons (Table 11 , Fig. 16). The 1961-80 period was marked by recruitment of the very strong 1959 and 1962 year-classes and the outstanding 1963 year-class. Subsequently, no year-classes of even average size were produced until 1975, although spawning stock biomass peaked at 314,000 tons in 1965 and did not decline below 100,000 tons until 1968.

Herrington (1948) obtained a dome-shaped stockrecruitment relationship for Georges Bank haddock by plotting, for 1914-40, commercial abundance index values for small (scrod) haddock against values for spawning adults (lagged 2-3 years). However, catcheffort data on which this analysis was based may not have been representative for earlier years (1914-30) (Herrington, 1948; Grosslein, MS 1966), thus casting doubt on the validity of this apparent relationship. Subsequent analyses based on more recent data (since 1931) have been inconclusive (Grosslein and Hennemuth, 1973). Similarly, no empirical basis for a stockrecruitment relationship was found in the present study (Fig. 16), although a tendency does appear evident for reduced recruitment at lower levels of stock abundance, as noted by Grosslein and Hennemuth (1973). During 1968-73, when spawning stock size

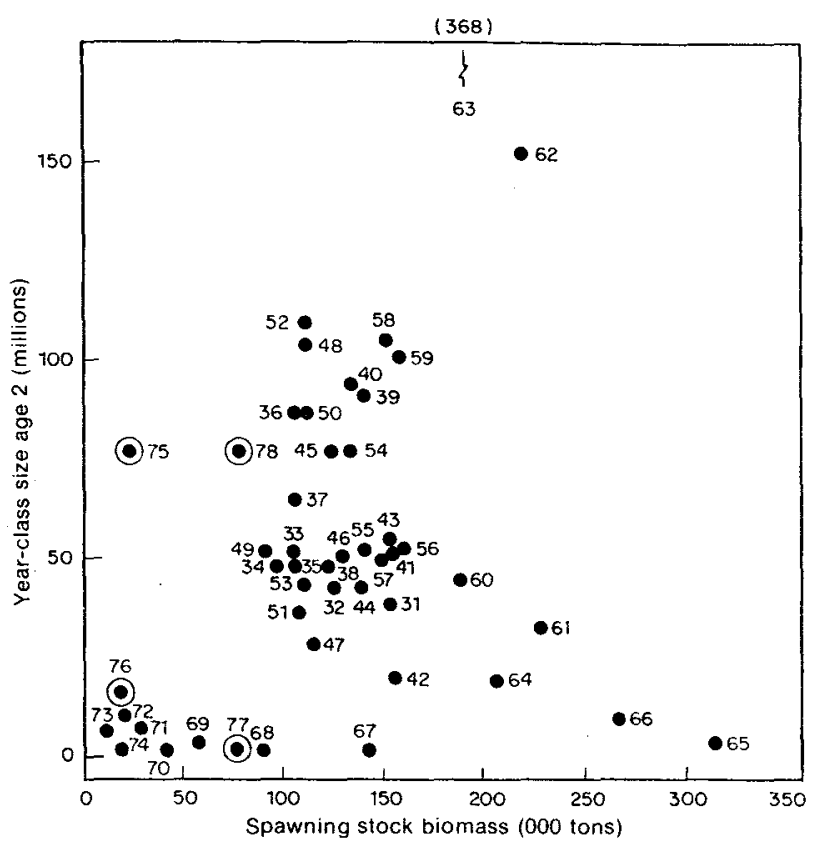

Fig. 16. Relation between recruiting year-class size (age 2) and spawning stock biomass (50\% of age 2 and $100 \%$ of age 3 and older fish) for Georges Bank haddock from virtual population analysis, 1931-78. (Predicted points are circled.) 
declined rapidly from 90,000 to 12,000 tons, no yearclasses of even average size were produced, and during 1974-77, when spawning stock size averaged 26,000 tons, only one such year-class was produced. However, full recruitment of the 1975 year-class to the spawning stock in 1978 was accompanied by the appearance of the strong 1978 year-class. Consequently, it might be inferred that recruitment is affected at low levels of abundance, although, in general, stock effects are probably obscured by environmental factors (Sissenwine et al., 1979; Hennemuth et al., 1980). In any event, maintenance of spawning biomass within a range of $100,000-160,000$ tons during 1935-60 did provide relative stability in recruiting year-class size, even in the absence of a quantifiable relationship.

\section{Gulf of Maine}

Available catch-at-age data for this stock are not sufficient for application of VPA, and accordingly trends in abundance have been evaluated primarily by examination of nominal catch and research-vessel survey data (Tables 1 and 3). Both sets of data indicate trends in abundance similar to those observed for Georges Bank, with precipitous declines from the early 1960 's to the mid-1970's and recovery in the late 1970's following recruitment of the 1975 year-class. However, the 1976-79 year-classes appear to have been much weaker and stock size has again declined following peak levels in 1977-78 (Table 3).

Nominal catches in 1977-78 (average of 4,250 tons) were comparable to those observed during 1964-68 (average of 4,915 tons). The estimated recreational catch in the Gulf of Maine for 1978 was in the order of 400-500 tons. Recreational catches in the mid1960 's are uncertain due to variability in the estimates, i.e. the 1965 estimate of 9,702 tons (Deuel and Clark, 1968) appears unrealistically high in view of the 1960 and 1970 estimates averaging 957 tons (Clark, 1962; Deuel, 1973). The pooled estimate of $Z$ for 1964-68 from autumn survey data was 0.58 , implying an $F$ of 0.38 (assuming $M=0.2$ ). Biomass levels for 1977-78 appear to have been comparable to those for 1964-68 (average autumn survey index values were $12.8 \mathrm{~kg}$ and $11.2 \mathrm{~kg}$ respectively).

Combination of the average annual nominal catch for 1964-68 (4,915 tons) and the average estimated recreational catch for 1960 and 1970 (957 tons) gives an average catch of 5,872 tons. Use of this value with the above estimates of $F$ and $Z$ in the equation

$$
C=\frac{F}{Z-G} B\left[1-e^{-(Z-G)}\right]
$$

where $C$ is average catch, $B$ is average stock biomass, $G$ is instantaneous growth rate $(0.44$ being the average for dominant age-groups 2-4 in the fishery), and $F$ and $Z$ are as previously defined, provides an average annual stock biomass of 16,000 tons for 1964-68. In view of the above-mentioned similarity of autumn survey index values for 1964-68 and 1977-78, it appears that stock biomass had increased by $1977-78$ to approximately the observed 1964-68 level.

\section{Summary and Conclusions}

The Georges Bank haddock stock has been intensively studied since 1930, and a large volume of biological and statistical data has been accumulated for assessment and management purposes. Important earlier papers dealt with evaluation of trends in abundance and harvest potential, stock identification, and environmental factors affecting year-class size. Interest during the 1950's was focused on gear selectivity and evaluation of mesh regulations, and more recent work has been oriented largely towards stock assessment.

Management originated under ICNAF in 1953, with implementation of a regulation specifying a minimum mesh size of 4.5 inches $(114 \mathrm{~mm})$ for Subarea 5. This regulation substantially increased harvesting efficiency and reduced discarding of haddock. The documented severe reduction of the Georges Bank stock during the 1960's led to more intensive management, including total allowable catches and closure of haddock spawning areas. Responsibility for management of the Georges Bank and Gulf of Maine haddock stocks was assumed by the USA New England Regional Fishery Management Council in early 1977, following the extension of jurisdiction over fisheries to 200 miles. Initially, previous ICNAF management measures were continued, but recruitment of the strong 1975 yearclass in 1977 and a rapid increase in USA harvesting capacity led to increased optimum yields in subsequent years.

Georges Bank haddock spawn between January and June, with peak activity in late March and April. Juveniles are pelagic in habit for several months but subsequently settle to the bottom for the rest of their lives. Approximately $50 \%$ of age 2 and $100 \%$ of age 3 and older haddock are sexually mature. The Georges Bank population east of the Great South Channel appears to be relatively isolated from those of adjacent areas, but one or two smaller units, which may intermingle to some degree, also exist in the Nantucket Shoals and western Gulf of Maine area.

Following high levels of exploitation in the late 1920 's, the Georges Bank haddock fishery entered a period of relative stability during 1935-60, with nominal catches averaging 46,000 tons. During this period, 
the fishery was prosecuted almost exclusively by USA vessels and catches were dominated by age 2-4 fish. Strong recruitment in the early to mid-1960's resulted in greatly increased fishing effort by Canadian and distant-water fleets. Nominal catches increased rapidly to 150,400 tons in 1965 and declined precipitously to an average of 4,700 tons during 1974-76, due primarily to poor recruitment in the late 1960's and early 1970's. During 1967-72, the fishery was supported largely by the remnant of the 1963 year-class. Subsequently, the catch on Georges Bank increased to 22,300 tons in 1978 due to recruitment of the strong 1975 year-class. Similar trends were evident for the Gulf of Maine haddock fishery, in which nominal catches declined from an average of 5,100 tons in $1959-66$ to only 600 tons in 1973 but increased to 5,200 tons in 1978. The 1963 year-class primarily supported the fishery during 1966-70 and the 1975 year-class dominated during 1977-79, the intervening yearclasses having been poor. Recreational catches of haddock in the Gulf of Maine appear to have fluctuated considerably, but the quantities taken in recent years were small (in the order of 400 tons).

Research vessel survey data for the Georges Bank-Gulf of Maine area indicate a decline in biomass of over $90 \%$ during 1964-74, with spawning stock size reaching an apparent all-time low in the early 1970's. Subsequently, catch per tow increased substantially with recruitment of the 1975 year-class. The 1978 yearclass was comparable in size to the 1975 year-class on Georges Bank but was much weaker in the Gulf of Maine. Changes in abundance on Georges Bank were accompanied by changes in geographical distribution and spatial density and a marked increase in variability in survey catch-per-tow data.

Analysis of survey data for Georges Bank indicates high levels of mortality $(Z>1.0)$ during the mid 1960 's, implying that $F$ substantially exceeded $F_{\max }$ during that period. Estimates of $Z$ were considerably lower (about 0.5) during 1968-72 but increased in subsequent years despite increasingly restrictive management. Estimates of $Z$ for the Gulf of Maine stock were generally lower than those for Georges Bank.

Growth rates for Georges Bank haddock were relatively stable during 1935-60 although declines occurred following periods of strong recruitment as evidenced by commercial weight-at-age data. In the early to mid-1960's, stock size rose to peak levels and growth rates again declined, but rapid increases occurred in the early to mid-1970's coincident with declining stock abundance. Increased growth rates appear to have resulted from increased food availability associated with reduced abundance. A tendency was evident for strong year-classes to have a depressing effect on the growth of succeeding year-classes. Von Bertalanffy growth equations based on length-at- age data from research vessels surveys in 1973-77 indicate slightly faster growth of haddock on Georges Bank than in the Gulf of Maine. For current regulation trawls ( $130 \mathrm{~mm}$ mesh codend), yield-per-recruit calculations indicate $F_{\max }$ values of 0.47 and 0.54 for Georges Bank and Gulf of Maine haddock respectively, with corresponding $F_{0.1}$ values of 0.23 and 0.25 .

During 1935-60 total stock size (age 2 and older) for Georges Bank fluctuated about an annual average of 140 million fish (153,000 tons) while spawning stock size averaged 109 million fish (131,000 tons). Recruitment was relatively stable, with almost $50 \%$ of the recruiting year-classes (age 2) being in the order of 40-50 million fish; the observed mean was 61 million fish with a range of 19-108 million fish. Recruitment of the very strong 1958, 1959 and 1962 year-classes and the outstanding 1963 year-class resulted in a pronounced increase in total stock size to 530 million fish $(427,000$ tons) in 1965 , while spawning stock size also peaked at 346 million fish (314,000 tons). Following heavy exploitation in the mid-1960's and with continued poor recruitment, total stock size declined precipitously to an average of 9 million fish (18,000 tons) in 1972-73. Fishing mortality on age 3 and older fish increased from an average of 0.44 during 1935-60 to 0.79 in 1966 but subsequently declined with reduced abundance and redirection of fishing effort to other stocks. No empirical basis was found for a stockrecruitment relationship, but a tendency was clearly evident for reduced (and more variable) recruitment at low levels of spawning stock size.

In 1977, stock size increased to about 84 million fish $(73,000$ tons), with recruitment of the strong 1975 year-class. Recent research vessel survey data indicate the 1978 year-class to be similar in size to the 1975 year-class, and the Georges Bank stock appears to be increasing, although it is clearly in a less stable condition than in former years. Since 1977, the fishery has been based essentially on a single year-class and this situation may continue for some time unless good year-classes appear more frequently. Continued dependence of the fishery on a single year-class implies a continued potential for wide fluctuations in recruitment and stock size.

\section{Acknowledgements}

We thank Bradford Brown and Michael Sissenwine for their criticisms and constructive comments during the preparation of the manuscript. Barry Armet, Ronald Essig, Ralph Mayo, Paul Wood and other staff members of the Northeast Fisheries Center assisted greatly with data tabulation, computer analysis and other phases of the work. The editorial comments and assistance piovided by V.M. Hodder and the reviewers is also sincerely appreciated. 


\section{References}

ABRAMSON, J. A. 1971. Computer programs for fish stock assessment. FAO Fish. Tech. Paper, No. 101.

ANDERSON, K. A. 1938. An investigation into the alteration in the growth rate of the haddock. ICES Rapp. Proc.-Verb., 108: 85-87.

BEVERTON, R. J. H. 1965. Catch-effort assessment in some ICNAF fisheries. ICNAF Res. Bull., 2: 59-72.

BEVERTON, R. J. H., and S. J. HOLT. 1957. On the dynamics of exploited fish populations. Fish. Invest. Minist. Agric. Fish. Food (G. B.) (2 Sea Fish), 19: 533 p.

BIGELOW, H. B., and W. C. SCHROEDER. 1953. Fishes of the Gulf of Maine. Fish. Bull. U. S., 53, 577 p.

BROWN, B. E., and R. C. HENNEMUTH. 1971. Length-weight relations of haddock from commercial landings in New England, 1931-55. U. S. Dept. Commer., NOAA Tech. Rep., NMFS SSRF-638, 13 p.

CHASE, J. 1955. Winds and temperature in relation to the brood strength of Georges Bank haddock. ICES J. Cons., 21: 17-24.

CLARK, J. R. 1952. Further experiments on the escape of undersized haddock through otter trawls. Comm. Fish. Rev., 14(12): 7-12.

1959. Sexual maturity of haddock. Trans. Amer. Fish. Soc. , 88: 212-213.

1962. The 1960 salt-water angling survey. Circ. U. S. Fish Wildl. Serv., No. 153, 36 p.

1963. Size selection of fish by otter trawls. ICNAF Spec. Publ. 5: 24-96.

CLARK, J. R., and F. A. DREYER. 1961. New England haddock fishery biostatistics, 1956. Spec. Sci. Rep. U. S. Fish Wildl. Serv. - Fish., No. $375,89 \mathrm{p}$.

CLARK, J. R., and V. D. VLADYKOV. 1960. Definition of haddock stocks of the northwestern Atlantic. Fish Bull. U.S., 60: 283-296.

CLARK, S. H. 1979. Application of bottom-trawi survey data to fish stock assessment. Fisheries, 4(3): 9-15.

CLARK, S. H., and R. J. ESSIG. MS 1980. Georges Bank and Gulf of Maine haddock assessment update. U.S. Nat. Mar. Fish. Serv., Northeast Fisheries Center, Woods Hole, Lab. Ref. Doc. No. 80-06, $33 \mathrm{p}$.

CLARK, S. H., and OVERHOLTZ. MS 1979. Review and assessment of the Georges Bank and Gulf of Maine haddock fishery. U.S. Nat. Mar. Fish. Serv., Northeast Fisheries Center, Woods Hole, Lab. Ref. Doc. No. 79-05, 68 p.

COLTON, J. B. 1955. Spring and summer distribution of haddock on Georges Bank. Spec. Sci. Rep. U. S. Fish Wildl. Serv. - Fish., No. $156,65 \mathrm{p}$

1965. The distribution and behavior of pelagic and early demersal stages of haddock in relation to sampling techniques. ICNAF Spec. Publ., 6: 317-333.

COLTON, J. B., and J. M. St. ONGE. 1974. Distribution of fish eggs and larvae in continental shelf waters, Nova Scotia to Long Istand. Amer. Geo. Soc. Serial Atlas Marine Env., Folio No. 23.

COLTON, J. B., and R. F. TEMPLE. 1961. The enigma of Georges Bank spawning. Limnol. Oceanogr., 6: 280-291.

DAVIS, C.W. 1978. Seasonal bottom-water temperature trends in the Gulf of Maine and on Georges Bank, 1963-1975. U. S. Dept. Commer., NOAA Tech. Rep., NMFS SSRF-725, $17 \mathrm{p}$.

DEUEL, D. G. 1973. The 1970 salt-water angling survey. U. S. Dept. Commer., Curr. Fish. Stat., No. 6200, 54 p.

DEUEL, D. G., and J. R. CLARK. 1968. The 1965 salt-water angling survey. U. S. Fish Wildl. Serv., Resour. Publ., No. 67, $51 \mathrm{p}$

GRAHAM, H. W. 1952. A minimum net-mesh size for the New England haddock fishery. Comm. Fish. Rev., 14(12): 1-6.

GRAHAM, H. W., and E. D. PREMETZ. 1955. First year of mesh regulation in the Georges Bank haddock fishery. Spec. Sci. Rep. U.S., Fish Wildl. Serv. - Fish., No. 142, 29 p.

GROSSLEIN, M. D. 1962. Haddock stocks in the ICNAF Convention Area. ICNAF Redbook 1962, Part III: 124-131.

MS 1966. Stock-recruitment of Georges Bank haddock. ICNAF Res. Doc., No. 74, Serial No. 1968.

1969. Groundfish survey program of BCF Woods Hole.
Comm. Fish. Rev., 31(8-9): 22-35.

MS 1969. Haddock recruitment predictions from bottom traw! catches of 0-group fish in Subarea 5 and Division $4 X$. ICNAF Res. Doc., No. 89, Serial No. 2255.

GROSSLEIN, M. D., and R. C. HENNEMUTH. 1973. Spawning stock and other factors related to recruitment of haddock on Georges Bank. ICES Rapp. Proc.-Verb., 164: 77-88.

GULLAND, J. A., and L. K. BOEREMA. 1973. Scientific advice on catch levels. Fish. Bull. U. S., 71: 325-335.

HALLIDAY, R. G., and F. D. MCCRACKEN. 1970. Movements of haddock tagged off Digby, Nova Scotia. ICNAF Res. Bull., 7: 8-14.

HENNEMUTH, R. C. 1965. Homogeneity of age-length frequencies among months and quarters of the year for haddock caught on Georges Bank, 1962. ICNAF Res. Bull., 2: 76-77.

MS 1968. Status of the Georges Bank haddock stock and effects of recent high levels of fishing effort. ICNAFRes. Doc., No. 92, Serial No. 2080.

MS 1969. Status of the Georges Bank haddock fishery. ICNAF Res. Doc., No. 90, Serial No. 2256.

HENNEMUTH, R. C., M. D. GROSSLEIN, and F. D. MCCRACKEN. 1964. Abundance, age composition of landings, and total mortality of haddock caught off southern Nova Scotia, 1956-1961. ICNAF Res. Bull., 1: 43-73.

HENNEMUTH, R. C., J.E. PALMER, and B. E. BROWN. 1980. A statistical description of recruitment in eighteen selected fish stocks. $J$. Northw. Atl. Fish. Sci., 1: 101-111.

HERRINGTON, W. C. 1935. Modifications in gear to curtail the destruction of undersized fish in otter trawling. U.S. Bur. Fish., Invest Rep., No. 24, 48 p.

1936. Decline in haddock abundance on Georges Bank and a practical remedy. Circ. U. S. Bur. Fish., No. 123, 22 p.

1948. Limiting factors for fish populations. Bull. Bingham Oceanogr. Coll., 11: 229-279.

HOLDEN, M. J. (Ed.). 1971. Report of the ICES/ICNAF Working Group on selectivity analysis. ICES COop. Res. Rep., 25, $114 \mathrm{p}$.

ICNAF, 1952. Report of the Second Annual Meeting, 30 June-9 July 1952. ICNAF Annu. Rep. 1951/52, p. 11-22.

1958-1980. Fishery statistics for the Northwest Atlantic for the years 1956-1978. ICNAF Stat. Bull., Vol. 6 to 28.

1969. Report of the 19th Annual Meeting, 2-7 June 1969 ICNAF Annu. Proc., 19: 14-39.

JONES, R. MS 1979. Relationship between mean length and year-class strength in North Sea haddock. ICES C. M., Doc. No. G:45.

JONES, R., and J. R. G. HISLOP. 1978. Changes in North Sea haddock and whiting. ICES Rapp. Proc.-Verb., 171: 58-72.

LAURENCE, G. C. 1974. Growth and survival of haddock (Melanogrammus aeglefinus) larvae in relation to planktonic prey concentration. J. Fish. Res. Bd. Canada, 31: 1415-1419.

LAURENCE, G. C., and C. A. ROGERS. 1976. Effects of temperature and salinity on comparative embryo development and mortality of Atlantic cod (Gadus morhua L.) and haddock (Molanogrammus aeglefinus (L.)).ICES J. Cons., 36: 220-228.

LAURENCE, G. C., A. S. SMIGIELSKI, T. A. HALAVIK, and B. R. BURNS. 1981. Implications of direct competition between larval cod (Gadus morhua) and haddock (Melanogrammus aeglefinus) in laboratory growth and survival studies at different food densities. ICES Rapp. Proc.-Verb., 178: 304-311.

MARAK, R. R., and R. LIVINGSTONE. 1970. Spawning dates of Subarea 5 haddock. ICNAF Res. Bull., 7: 56-58.

MAURER, R. O., and R. E. BOWMAN. MS 1975. Food habits of marine fishes of the Northwest Atlantic - data report. U. S. Nat. Mar. Fish. Serv., Northeast Fisheries Center, Woods Hole, Lab. Ref. Doc. No. 75-3, 90 p.

McCANN, J. A., and F. A. DREYER. 1963. Length and age frequency samples collected from Georges Bank haddock landings, 19311955. Spec. Sci. Rep. U. S. Fish Wildl. Serv. - Fish., No. 438, 127 p.

MCCRACKEN, F. D. 1960. Studies of haddock in the Passamaquoddy Bay region. J. Fish. Res. Bd. Canada, 17: 175-180.

NAFO. 1981. Fishery statistics for the Northwest Atlantic for the year 1979. NAFO Stat. Bull., Vol. 29. 
NEEDLER, A. W. H. 1930. The migrations of haddock and the interrelationships of haddock populations in North American waters. Contrib. Can. Biol., 6: 243-313.

NICHOLSON, L. E., and R. P. RUAIS. MS 1979. Description of the recreational fisheries for cod, haddock, pollock, and silver hake off the northeast coast of the United States. New England Regional Fishery Management Council, Saugus, Mass., U.S.A., 110 p.

PAULIK, G. J., and L. E. GALES. 1964. Allometric growth and the Beverton-Holt yield equation. Trans. Amer. Fish. Soc., 93: 369-381.

PENNINGTON, M. R., and M. D. GROSSLEIN. MS 1978. Accuracy of abundance indices based on stratified-random trawl surveys. ICNAF Res. Doc. No. 77, Serial No. 5264.

POPE, J. A., A. R. MARGETTS, J. M. HAMLEY, and E. F. AKYUZ. 1975. Manual of methods for fish stock assessment. Part III. Selectivity of fishing gear. FAO Fish. Tech. Paper, No. 41,65 p.

POSGAY, J. A., and R. R. MARAK. 1970. The number of haddock spawning on Georges Bank as estimated from egg surveys. ICNAF Redbook 1970, Part III: 96-102.

POWER, E. A. 1958. United States haddock fishery, 1880-1956. U.S. Fish Wildl. Serv., Fishery Statistics of the United States 1956, p. 432-434

PREMETZ, E. D. 1953. Destruction of undersized haddock on Georges Bank, 1947-1951. Spec. Sci. Rep. U. S. Fish Wildl. Serv., - Fish., No. $96,33 \mathrm{p}$.

RAITT, D. S. 1939. The rate of mortality of the haddock of the North Sea stock, 1919-1938. ICES Rapp. Proc-Verb., 110: 65-79.

RIDGELY, J. E., and D. G. DEUEL. MS 1976. Participation in marine recreational fishing, northeastern United States, 1973-1974, Phase II.

ROUNSEFELL, G. A. 1948. Development of fishery statistics in the North Atlantic. Spec. Sci. Rep. U. S. Fish WildI. Serv. - Fish., No. $47,18 \mathrm{p}$.

1957. A method of estimating abundance of groundfish on Georges Bank. Fish. Bull. U. S., 57: 265-278.

ROYCE, W. F., and H. A. SCHUCK. 1954. Studies of Georges Bank haddock, Part Ill: Prediction of the catch. Fish. Bull. U.S., 56: 1-6.

SCHROEDER, W. C. 1942. Results of haddock tagging in the Gulf of Maine from 1923 to 1943. J. Mar. Res., 5: 1-19.

SCHUCK, H. A. 1949. Relationship of catch to changes in population size of New England haddock. Biometrics, 5: 213-231.

1951. Studies of Georges Bank haddock, Part 1: Landings by pounds, numbers, and sizes of fish. Fish. Bull. U. S., 52: 151-176.
SCHUCK, H. A., and E. L. ARNOLD. 1951. Comparison of haddock from Georges and Browns bank. Fish. Bull. U. S., 52: 177-185.

SISSENWINE, M.P., B. E. BROWN, and J. BRENNAN-HOSKINS. 1979. Brief history and state of the art of fish production models and some applications to fisheries of the northeastern United States. Proc. Climate and Fisheries Workshop, Univ. Rhode Island, Kingston, p. 25-48.

SMITH, K. A., and F. L. OLSEN. MS 1976. Brief historical synopsis of certain northeast U. S. fisheries. U. S. Nat. Mar. Fish. Serv., Northeast Fisheries Center, Woods Hole, Lab. Ref. Doc., No. 76-11, $24 \mathrm{p}$.

SMOLOWITZ, R. J. MS 1978. New England mesh selectivity studies, experiment three, offshore groundfish. U.S. Nat. Mar. Fish. Serv., Northeast Fisheries Center, Woods Hole, Lab. Ref. Doc., No. 78$48,39 p$.

SONINA, M. A. 1965. Relation between the growth rate and population density of haddock in the Barents Sea. ICNAF Spec. PubI., 6 : 565-570.

1969. Biology of the Arcto-Norwegian haddock during 1927-1965. Trudy PINRO, 26: 3-124. (Fish. Res. Bd. Canada Transl. Ser., No. 1924, 1971.)

STERN, H., and R. C. HENNEMUTH. 1975. A two-way model for estimating standardized fishing effort applied to the U. S. haddock fleet. ICES Rapp. Proc.-Verb., 168: 44-49.

TEMPLEMAN, W., and C. A. BISHOP. 1979. Age, growth, year-class strength and mortality of haddock, Melanogrammus aeglefinus, on St. Pierre Bank in 1948-1975 and their relation to the haddock fishery of this area. ICNAF Res. Bull., 14: 85-99.

TEMPLEMAN, W., V. M. HODDER, and R. WELLS. 1978. Age, growth, year-class strength and mortality of the haddock, Melanogrammus aeglefinus, on the southern Grand Bank and their relation to the haddock fishery of this area. ICNAF Res. Bull., 13: 31-52.

US DEPT. COMMERCE. 1980. Marine recreational fishery statistics survey, Atlantic and Gulf coasts, 1979. U. S. Dept. Commer., Curr. Fish. Stat., No. 8063, 139 p.

WALFORD, L. A. 1938. Effects of currents on distribution and survival of the eggs and larvae of haddock (Melanogrammus aeglefinus) on Georges Bank. Bull. U. S. Bur. Fish., 49: 1-73.

WIGLEY, R. L. 1956. Food habits of Georges Bank haddock. Spec. Sci. Rept. U. S. Fish Wildl. Serv. - Fish., No. 165, 26 p

WIGLEY, R. L., and R. B. THEROUX. 1965. Seasonal food habits of highlands ground haddock. Trans. Amer. Fish. Soc., 94: 243-251. 
